ISSN 0819-2642

ISBN 0734025718

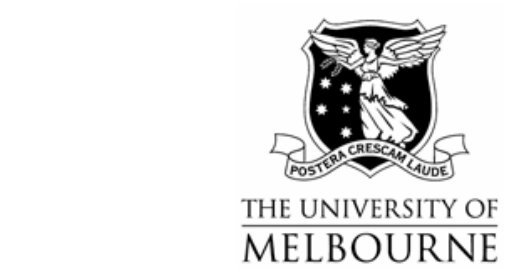

THE UNIVERSITY OF MELBOURNE

DEPARTMENT OF ECONOMICS

RESEARCH PAPER NUMBER 915

SEPTEMBER 2004

TESTING FOR EMPLOYEE DISCRIMINATION USING MATCHED EMPLOYER-EMPLOYEE DATA:

THEORY AND EVIDENCE

by

Paul Frijters

\&

Michael A. Shields

$\&$

Nikolaos Theodoropoulos

\&

Stephen Wheatley Price

Department of Economics The University of Melbourne Melbourne Victoria 3010 Australia. 


\title{
Testing for Employee Discrimination using Matched Employer-Employee Data: Theory and Evidence*
}

\author{
by \\ Paul Frijters $^{a}$, Michael A. Shields ${ }^{b}$, Nikolaos Theodoropoulos ${ }^{c}$ and Stephen Wheatley \\ Price $^{d}$
}

\begin{abstract}
We use recent matched employer-employee data to directly investigate if white workers have a taste for racial discrimination in Britain. Based on a new structural model with individual and firm heterogeneity, we develop and test two predictions. Firstly, white employees with a taste for discrimination should report lower levels of job satisfaction the larger the proportion of ethnic minorities at their workplace. Secondly, white employees would have to be compensated by higher wages if required to work alongside ethnic minority co-workers. Both hypotheses are clearly supported for white males in our data, after comprehensively controlling for individual, job, and workplace characteristics. However, the evidence is weaker for females. The white male wage premium for working amongst only ethnic minority co-workers, as compared to working only with whites, is about $12 \%$. Importantly, it appears that neither of these effects operates via realised racial prejudice at the workplace or white employees' feelings concerning their job security.
\end{abstract}

Keywords: Employee Discrimination, Compensating Differentials, Structural Estimation, Wages, Job Satisfaction

JEL Classifications: J3, J7

${ }^{* a}$ RSSS, Australian National University, Canberra, Australia; ${ }^{b}$ Department of Economics, University of Melbourne, Australia; ${ }^{c}$ Department of Economics, University College London, UK; ${ }^{d}$ Department of Economics, University of Leicester, UK. The usual disclaimer applies. This is a revised version of the paper with the same title published as IZA Discussion Paper no. 807 in June 2003 (see www.iza.org). 


\section{Introduction}

Since the seminal studies by Gary Becker (1957, 1971), issues surrounding the existence, extent and persistence of discrimination in the labour market, and more widely in the legal system, financial markets, housing, education and other public services, have generated an enormous amount of interest by economists and social scientists. Recent informative reviews of both the theoretical and empirical economics literature in this area can be found in Cain (1986), Darity and Mason (1998), Altonji and Blank (1999) and Riach and Rich (2002). Of all the possible grounds for discrimination, for example with respect to gender, race, disability, age or sexual preference, perhaps the most emotive branch of this literature regards unequal treatment on the basis of race or ethnicity. According to Arrow (1998), even after three or four decades of equal opportunities legislation in many countries including the US, such discrimination still 'pervades every aspect of a society in which it is found'. In the labour market this has been shown to apply to employment prospects, the receipt of employer-provided training, the probability of being promoted and wages (Altonji and Blank, 1999). However, it is clearly evident that the most blatant forms of racial discrimination such as forced or legalised racial segregation in labour markets and public services are no longer prevalent in developed countries (Arrow, 1998; Altonji and Blank, 1999).

Recent decades have seen a great deal of theoretical work concerned with the possible mechanisms via which individuals from different racial or ethnic minority backgrounds can be observed earning different amounts, even at the same productivity level. Following the theoretical advancements of Becker $(1957,1971)$, a core explanation for racial discrimination is based on economic agents having a taste or preference against other groups, which can be held by employers, employees, consumers or the government. A recent new angle to this literature concerns the importance of identity. For example, Akerlof and Kranton (2000) directly include identity into the utility function, which then leads individuals to be prepared to suffer loss of income in order to discriminate against other groups. Frijters (1998) models the emergence of group identity itself as the outcome of rational individuals attempting to monopolise rents. Group identity then, ex post, implies discrimination of 
the group that lost the competition over scarce rents.

In contrast, virtually all other explanations for observed racial differentials are nonpreference based, with theories based on 'statistical' or information-based discrimination being the most prominent (see, for example, Phelps, 1972; Arrow, 1973; Altonji and Pierret, 2001; Knowles et al., 2001). Statistical discrimination can work through, for example, employers believing there is something wrong with the discriminated group, such as a higher probability of women leaving the labour market (Polachek, 1995), greater difficulty in observing the quality of the workers, or a comparative advantage in a different field of activity (e.g. Becker, 1991; Lazear and Rosen, 1990). A second class of statistical discrimination models explains discrimination as a self-fulfilling prophesy (e.g. Arrow, 1973; Coate and Loury, 1993; Kremer, 1993; Lang, 1986; Farmer and Terell, 1996), whereby low expectations of the average productivity of a group lead individuals to undertake actions which make the expectation come true, such as making lower investments in human capital (Kremer, 1993), or applying for jobs for which one is not suited (Rosén, 1997). Weaker versions of the self-fulfilling prophecy argument suggest that persistence in expectations of differential productivity lead groups to segregate into different occupations or human capital levels, thereby perpetuating initial disadvantages (e.g. Breen and Garcia, 2002).

However, empirically distinguishing between these competing explanations remains very difficult (see Heckman, 1998), and consequently there is no dominant view about how racial discrimination perpetuates itself in the labour market. The ability to correctly identify the causal mechanisms by which racial discrimination occurs and persists is, however, crucial for designing and introducing the appropriate policy response (Neumark, 1999; Bayard et al., 2003).

Whilst the majority of the empirical literature stems from the US, recent years have seen a number of papers focusing on racial or ethnic minority discrimination in the British labour market. Racism continues to be a prominent political issue in Britain, with recent attention focused on the existence of 'institutional racism' in large private corporations, such as Ford, and in the public sector, including the National Health Service, the police and the armed forces. For example, Shields and Wheatley Price (2002a, 2002b) document 
that the majority of ethnic minority nursing staff report having experienced racial harassment from co-workers and also show that frequent episodes of this form of employee discrimination have the largest detrimental impact of their job satisfaction. Further evidence of racially prejudiced attitudes in Britain is provided by Dustmann and Preston (2001). Using data from the British Social Attitudes Survey they found that $20 \%$ of the white respondents would mind if their boss was from an ethnic minority, $38 \%$ reported being at least a little prejudiced against people of other races and $53 \%$ would mind if a close relative married someone from an ethnic minority. Interestingly, the strength of these racial hostility indicators increased with the concentration of ethnic minorities in the neighbourhood. Furthermore, it appears that it is racial prejudice, rather than economic fears (e.g. over job security), which dominates concerns about the impact of immigration in Britain (Dustmann and Preston, 2002; see Borjas, 1999, more generally).

In common with studies for other countries, employer discrimination, based on tastes, is typically taken as the dominant explanation for racial or ethnic disadvantage in the British labour market. Moreover, in contrast to the case of gender (Blackaby et al., 1997; Tzannatos, 1988), it is widely accepted that the equal opportunities legislation successively introduced in Britain since the Race Relations Act of 1976, has been less successful in reducing racial differentials in the labour market, with ethnic minorities becoming increasingly concentrated in the lower percentiles of the pay distribution (Blackaby et al., 1994, 2002). Numerous studies have found evidence of more limited employment prospects (e.g. Blackaby et al., 1997, 1998, 2002), fewer training and promotion opportunities (e.g. Pudney and Shields, 2000a, 2000b), and lower occupational attainment (e.g. Stewart, 1983) and wages (e.g. Blackaby et al., 1998, 2002; Dustmann and Fabri, 2003) for ethnic minority groups, compared to similar white workers in Britain. However, these findings constitute, at best, only indirect evidence of the extent and nature of discrimination.

In this paper we aim to contribute more direct evidence of the extent of racial discrimination at the workplace, using, recently collected, matched employer-employee data from Britain, which uniquely allows us to establish the racial or ethnic composition of workplaces. The detailed data also provides information on workers job satisfaction and wages, together with a wide range of workplace characteristics with which we attempt 
to comprehensively capture heterogeneity in the quality of the job and the general working environment. Our particular focus is on identifying if white employees have a taste for discrimination against their ethnic minority co-workers. Of all the competing theories of racial discrimination, there are relatively very few studies that have attempted to explore whether such employee tastes exist (for example, see the limited number of studies mentioned in the recent reviews noted above). However, one notable exception is Chiswick (1973) who, using state-level variation in racial density in the US, found that white employee discrimination was important in explaining racial differentials in wages. In particular, white workers of a given skill level were found to receive compensation in the form of higher weekly wages if they worked with non-whites.

To justify our empirical analysis we expand Becker's theoretical model of employee discrimination to include both worker and firm heterogeneity. The theory provides two clear predictions that we empirically test. Firstly, if white employees truly have a taste for discrimination, then their job satisfaction will be lower, the higher the concentration of ethnic minority co-workers. Secondly, we should also observe higher pay for white employees, working amongst higher concentrations of ethnic minority co-workers, as a compensating differential. Furthermore, our detailed workplace data enables us to delve deeper into the actual mechanisms by which discriminatory tastes manifest themselves. In particular, since managers report if there have been racial tensions at their workplace, we can address the question of whether it is merely the presence of ethnic minority co-workers that bothers white employees, or whether it is the racial tension itself that is the cause of an unhappy working environment. Similarly, by using self-reported information on job-insecurity, we explore whether it is the impact of ethnic minority co-workers on white workers' perceptions of job (in)security that gives rise to a taste for racial discrimination.

In using matched employer-employee data we also contribute to the recent literature that has used such data to obtain a better understanding of the workings of the labour market (see Abowd and Kramarz, 1999; Haltiwanger et al., 1999; Hamermesh, 1999). Most of these studies have used US data from the Worker-Establishment Characteristics Database (WECD) and a matching of the Sample Edited Detail File (SEDF) to establishment records in the 1990 Standard Statistical Establishment List (SSEL). Of the small 
literature that has focused on sex and racial discrimination three recent examples are Carrington and Troske (1998), Hellerstein and Neumark (2002) and Bayard et al. (2003). The latter study found that segregation of women in lower-paying occupations, industries and establishments accounted for around half of the gender wage gap. Importantly, with respect to the analysis presented in this paper, Carrington and Troske (1998) found that the inter-firm distribution of black and white workers was close to that implied by random assignment. They also cite evidence that black and white workers in the same firm often have different skills, and that the black-white wage gap in the US is primarily a within-firm phenomenon. Hellerstein and Neumark (2002) use new data from the new Decennial Employer-Employee Dataset (DEED) and find that Hispanics, but not white workers, suffer wage penalties from employment in a workplace with a large share of Hispanic workers.

The outline of this paper is as follows. In Section 2 we build on the model of Becker $(1957,1971)$ by presenting two formal theories of discrimination, via which we can structurally estimate the presence of employee tastes for racial discrimination. Importantly, we expand the basic model to include both worker and firm heterogeneity. The matched employer-employer data we use, which uniquely contains information about the racial or ethnic composition of the workplace, is described in Section 3, together with the derivation of our main variables of interest. Section 4 outlines the empirical models we use to test the two main predictions of the theory. The results from these models are discussed in Section 5, and Section 6 concludes the paper.

\section{Theory}

In this section we present two related models of employee based labour market discrimination. The first model is a simple partial-equilibrium compensating differentials model in which we do not explicitly allow for firm behaviour. This model clearly generates our two main predictions, which we later empirically test using matched employer-employee data. In order to investigate whether these predictions also apply to a situation with endogenous firm behaviour, we then develop an extended version of Becker's $(1957,1991)$ taste for discrimination model in which workers hold preferences about the racial composition of 
their co-workers. Importantly, in this extension we allow for both heterogeneous workers and firms.

\subsection{A partial-equilibrium compensating differential model}

We begin by writing the indirect utility function of an ethnic minority worker $i$ at job (or workplace) $k$ as being a function of job satisfaction, individual characteristics, and wages:

$$
\begin{aligned}
u_{i k} & =U\left(J S_{i k}, w_{i k}, x_{i}\right) \\
J S_{i k} & =J S\left(w_{i k}, e t h_{k}, x_{i}, z_{k}\right)
\end{aligned}
$$

where $J S_{i k}$ is the job satisfaction of individual $i$ at job $k ; w_{i k}$ is the total amount of wages of individual $i$ at job $k$; et $h_{k}$ is the density of ethnic minority workers at job $k ; x_{i}$ is a set of individual characteristics, and $z_{k}$ is a set of characteristics of job $k$. We assume that both $U($.$) and J S($.$) are differentiable, increasing in w_{i k}$, and continuous. By definition,

a taste for discrimination on the part of white workers implies $\frac{\partial J S_{i k}}{\partial e t h_{k}}<0$. Given that we observe the job satisfaction of workers in the data set that we will use, we can check this prediction if we also comprehensively control for other variables. Therefore, our first hypothesis is:

Hypothesis 1: Given wages, firm, and individual characteristics, job satisfaction is lower for white workers when there is a higher density of ethnic minority co-workers at the workplace.

In a free-mobility equilibrium where there is a distribution of $e t h_{k}$ for white workers with the same individual characteristics, it has to be the case that these individuals are indifferent between working at their job and working at another job. This in turn means that at the margin:

$$
\frac{d u_{i k}}{d e t h_{k}}=0
$$


which implies:

$$
\frac{\partial U_{i k}}{\partial J S_{i k}}\left(\frac{\partial J S_{i k}}{\partial e t h_{k}}+\frac{\partial J S_{i k}}{\partial w_{i k}} \frac{d w_{i k}}{d e t h_{k}}\right)+\frac{\partial U_{i k}}{\partial w_{i k}} \frac{d w_{i k}}{d e t h_{k}}=0
$$

and hence:

$$
\frac{d w_{i k}}{d e t h_{k}}=\frac{-\frac{\partial U_{i k}}{\partial J S_{i k}} \frac{\partial J S_{i k}}{\partial \operatorname{eth}_{k}}}{\frac{\partial U_{i k}}{\partial J S_{i k}} \frac{\partial J S_{i k}}{\partial w_{i k}}+\frac{\partial U_{i k}}{\partial w_{i k}}}>0
$$

which shows that white workers have to be compensated for working with ethnic minority co-workers. This feature of an equilibrium leads us to our second hypothesis:

Hypothesis 2: If employees have a taste for discrimination then, given firm and individual characteristics, wages should be higher for white workers when there are higher proportions of ethnic minority co-workers at the workplace.

Importantly, this result crucially assumes that there are no market imperfections that would prevent white workers flowing from one firm to another. Given such free mobility however, it is clear that firms with many ethnic minority co-workers have to pay higher wages to whites in order to attract white workers.

Now, we can complicate this simple model by hypothesising that there are intervening mechanisms via which a taste for discrimination may work. To be precise, we can postulate that:

$$
\begin{aligned}
J S_{i k} & =J S\left(w_{i k}, x_{i}, z_{k}, g_{i k}\right) \\
g_{i k} & =g\left(e t h_{k}\right)
\end{aligned}
$$

where $g($.$) can be a stochastic function.$

In words, this would imply that $e t h_{k}$ works via another measurable variable $g_{i k}$. We should then find that $g_{i k}$ is a factor explaining job satisfaction and compensating wage differentials. What identifies $g$ as the 'intervening' factor, apart from theoretical considerations, would be that the effect of eth $h_{k}$ on $J S_{i k}$, conditional on $g_{i k}$, becomes zero, and that the effect of $e t h_{k}$ on $w_{i k}$ conditional on $g_{i k}$ becomes zero. In our empirical analysis we will examine the two most prominent candidates for this intervening mechanism. The first is the level of racial tension at the workplace, as reported by the workplace manager. 
This is a direct indicator of an uneasiness between white and ethnic minority workers. The second is the degree to which individuals feel insecure in their job, which has often been argued by sociologists to be a major explanation for discrimination (e.g. Cassirer, 1996).

\subsection{A general equilibrium model of employee tastes for racial discrimination}

We now explore the nature of the competitive environment in which the above predictions will also hold. To this aim, we extend Becker's (1957, 1971) model of discrimination, to include both individual and firm heterogeneity. This allows for firms with different ethnic minority densities and for individuals with different skill levels. Importantly, these assumptions are supported by recent empirical evidence. Carrington and Troske (1998) and Hellerstein and Neumark (2004) found that black and white workers in the same firm often have very different skills. They also found that the inter-firm distribution of black and white workers was close to that implied by random assignment.

We first simplify the indirect utility function for white workers:

$$
\begin{aligned}
u_{i k} & =J S_{i k}+\gamma_{1} \ln w_{i k}+f_{1}\left(x_{i}\right) \\
J S_{i k} & =\gamma_{2} \ln w_{i k}+\delta_{1} e t h_{k}+f_{2}\left(x_{i}\right)
\end{aligned}
$$

where $f_{1}($.$) and f_{2}($.$) are arbitrary functions of individual characteristics. We can estimate$ the second equation directly with our data. Some aspects of the first equation we can estimate indirectly, i.e. via observed wages.

As a normalisation we set $\gamma_{1}+\gamma_{2}=1$. This means the indirect decision-utility function reads:

$$
u_{i k}=\ln w_{i k}+\delta_{1} e t h_{k}+\left[f_{1}\left(x_{i}\right)+f_{2}\left(x_{i}\right)\right]
$$

where a taste for discrimination would imply that $\delta_{1}<0$. Now, we can introduce individual heterogeneity by proposing that each white individual $i$ has an efficiency number $q_{i}^{w h}$ of 'white skills'. The total measure of white individuals is 1 , and the cumulative distribution of white efficiency numbers is denoted as $Q^{w h}(q)$. We assume that this distribution has 
finite mean and that $Q^{w h}(0)=0$. This last assumption essentially means that we assume every worker has a positive marginal product. Hence we can interpret the unemployed as having $q^{w h}=0$.

For ethnic minority workers, we take the same indirect utility framework and label them by $j$ :

$$
u_{j k}=\ln w_{j k}+\delta_{2} e t h_{k}+\left[f_{3}\left(x_{j}\right)+f_{4}\left(x_{j}\right)\right]
$$

Each ethnic minority worker $j$ has an efficiency number $q_{j}^{e m}$ of 'ethnic minority skills'. The total measure of ethnic minority individuals is $\eta$ and the cumulative distribution of ethnic minority efficiency numbers is denoted by $Q^{e m}(q)$. Again, we assume that this distribution has finite mean and that $Q^{e m}(0)=0$.

There is also a continuum of active firms in the economy. Following Becker, we take a Cobb-Douglas production structure to explain why workers of different ethnicities work together in the first place. More precisely, workplace $k$ is characterised by a production function:

$$
y_{k}=W H_{k}^{1-\alpha_{k}} E M_{k}^{\alpha_{k}}
$$

Here, $W H_{k}$ denotes the number of efficiency units of white skill that is employed in workplace $k$. Also, $E M_{k}$ denotes the number of efficiency units of ethnic minority skill employed in workplace $\mathrm{k}$, and $\alpha_{k} \in[0,1]$ is a production parameter specific to workplace $k$. The cumulative distribution of $\alpha_{k}$ is denoted by $A\left(\alpha_{k}\right)$ and we assume it is increasing and differentiable everywhere on $\alpha_{k} \in\langle 0,1\rangle$. There can be positive mass-points at $\alpha_{k}=0$ and $\alpha_{k}=1$. This parameter allows for firms with only white workers (i.e. when $\alpha_{k}$ equals 0 ), or only ethnic minority workers (when $\alpha_{k}$ equals 1 ), or a mix (when $0<\alpha_{k}<1$ ). By definition, $e t h_{k}=E M_{k} /\left(E M_{k}+W H_{k}\right)$.

For each individual firm $k$, the price of output is a decreasing function $\mathrm{p}\left(y_{k}\right)$. We assume that this function is continuous and differentiable for $y_{k}>0$, that $\frac{\partial^{2} p\left(y_{k}\right) y_{k}}{\partial^{2} y_{k}}<0$ (i.e. decreasing marginal benefit), that $\lim _{y_{k} \downarrow 0} p\left(y_{k}\right) \rightarrow+\infty$, and that $\lim _{y_{k} \rightarrow \infty} p\left(y_{k}\right) \rightarrow 0$. These standard assumptions guarantee that firm size will always be non-zero and finite.

Solving this model, the main result is that utility maximisation leads to wage schedules 
satisfying $w_{i k}^{w h}=e^{-\delta_{1} e t h_{k}} w_{0}^{w h} q_{i}^{w h}$ and $w_{j k}^{e m}=e^{-\delta_{2} e t h_{k}} w_{0}^{e m} q_{j}^{e m}$. Here, $w_{0}^{w h}$ denotes the wage for white workers in completely white workplaces. Its value, together with $w_{0}^{e m}$, will be solved by firm behaviour. The term $e^{-\delta_{1} e t h_{k}}>1$ equals the compensating differential that white workers have to be given to work in workplace $k$. Under these wage schedules, all workers are indifferent about where they will work and a distribution of ethnic minority densities can be observed. We will be able to directly estimate these wage equations in the empirical part.

The profit function of firm $k$ reads:

$$
\pi_{k}=p_{k}\left(y_{k}\right) y_{k}-E M_{k} e^{-\delta_{2} e t h_{k}} w_{0}^{e m}-W H_{k} e^{-\delta_{1} e t h_{k}} w_{0}^{w h}
$$

Since the cost function is homogeneous of degree one and the production function is constant-returns to scale, the cost-minimising ratio $\frac{E M_{k}}{E M_{k}+W H_{k}}$ at relative wages $\frac{w_{0}^{w h}}{w_{0}^{e m}}$ is the same for each level of $y_{k}$. Denote the optimal ratio as $e t h_{k}^{*}\left(\frac{w_{0}^{w h}}{w_{0}^{e m}}\right)$. Now, for most parameter values $\left\{\delta_{1}, \delta_{2}, \alpha_{k}\right\}$, it is the case that et $h_{k}^{*}\left(\frac{w_{0}^{w h}}{w_{0}^{e m}}\right)$ is differentiable in $w_{0}^{w h}$ and $w_{0}^{e m}$ everywhere. However, for some values of $\left\{\delta_{1}, \delta_{2}, \alpha_{k}\right\}$ there are discontinuities in $e_{t} h_{k}^{*}\left(\frac{w_{0}^{w h}}{w_{0}^{e m}}\right)$ where $\lim _{\frac{w_{0}^{w h}}{w_{0}^{e m} \downarrow c}} e t h_{k}^{*}\left(\frac{w_{0}^{w h}}{w_{0}^{e m}}\right)>e^{e t} h_{k}^{*}(c)$ at any discontinuity point c. ${ }^{1}$ There trivially holds:

$$
\begin{aligned}
\operatorname{eth}_{k}^{*}\left(\frac{w_{0}^{w h}}{w_{0}^{e m}}\right) & =1 \text { iff } \alpha_{k}=1 \\
\text { eth }_{k}^{*}\left(\frac{w_{0}^{w h}}{w_{0}^{e m}}\right) & =0 \text { iff } \alpha_{k}=0 \\
0 & <\text { eth } h_{k}^{*}\left(\frac{w_{0}^{w h}}{w_{0}^{e m}}\right)<1 \text { iff } 0<\alpha_{k}<1
\end{aligned}
$$

and in the generic case $\frac{\partial e t h_{k}^{*}\left(\frac{w_{0}^{w h}}{\left.w_{0}^{e}\right)}\right)}{\partial \alpha_{k}}>0$. Except at boundary values for $\alpha_{k}$, we can write $E M_{k}=\left(\frac{e t h_{k}^{*}}{1-e t h_{k}^{*}}\right)^{1-\alpha} y_{k}$ and $W H_{k}=\left(\frac{1-e t h_{k}^{*}}{e t h_{k}^{*}}\right)^{\alpha} y_{k}$. Because the minimum of the cost function,

\footnotetext{
${ }^{1}$ We can illustrate this with a simple example. Take $\alpha_{k}=0.8, \delta_{1}=-0.1$ and $\delta_{2}=4$. There is then a discontinuity in $e t h_{k}^{*}\left(\frac{w_{0}^{w h}}{w_{0}^{e m}}\right)$ at $\frac{w_{0}^{e m}}{w_{0}^{w h}} \approx 16.7$. More generally, we can specify a region $\delta_{1}<\Delta^{*}(\alpha)$ for which $W H_{k} e^{-\delta_{1} e t h_{k}} w_{0}^{w h}$, the second part of the cost function, is no longer convex and discontinuities

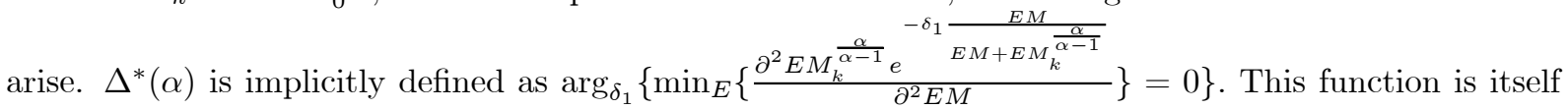
decreasing, though it's second derivative can be positive. For $0>\delta_{1}>\Delta^{*}(\alpha)$ and $\delta_{2}<0$, the cost function is strictly convex and $e t h_{k}^{*}\left(\frac{w_{0}^{w h}}{w_{0}^{e m}}\right)$ is therefore differentiable everywhere.
} 
given $y_{k}$, is differentiable in $w_{0}^{w h}$ and $w_{0}^{e m}$, there is a unique and differentiable implicit function $y_{k}\left(w_{0}^{w h}, w_{0}^{e m}\right)$.

What needs to be checked now is whether equilibrium actually exists and is unique. For this purpose, we can define total market demand functions $\mathrm{D}($.$) for E M$ and $W H$ :

$$
\begin{aligned}
D^{E M}\left(w_{0}^{w h}, w_{0}^{e m}\right)= & \int_{0}^{1^{-}} y_{k}\left(w_{0}^{w h}, w_{0}^{e m}\right)\left(\frac{e t h_{k}^{*}\left(\frac{w_{0}^{w h}}{w_{0}^{e m}}\right)}{1-e t h_{k}^{*}\left(\frac{w_{0}^{w h}}{w_{0}^{e m}}\right)}\right)^{1-\alpha} d A\left(\alpha_{k}\right) \\
& +\left(1-A\left(1^{-}\right)\right) y_{k}\left(w_{0}^{w h}, w_{0}^{e m}\right) \\
D^{W H}\left(w_{0}^{w h}, w_{0}^{e m}\right)= & \int_{0^{+}}^{1} y_{k}\left(w_{0}^{w h}, w_{0}^{e m}\right)\left(\frac{1-e t h_{k}^{*}\left(\frac{w_{0}^{w h}}{w_{0}^{e m}}\right)}{e t h_{k}^{*}\left(\frac{w_{0}^{w h}}{w_{0}^{e m}}\right)}\right)^{\alpha} d A\left(\alpha_{k}\right) \\
& +A(0) y_{k}\left(w_{0}^{w h}, w_{0}^{e m}\right)
\end{aligned}
$$

Market equilibrium now requires that a set $\left\{w_{0}^{w h}, w_{0}^{e m}\right\}$ exists for $D^{E M}\left(w_{0}^{w h}, w_{0}^{e m}\right)=$ $\eta \int q d Q^{e m}(q)$ and $D^{W H}\left(w_{0}^{w h}, w_{0}^{e m}\right)=\int q d Q^{w h}(q)$. The right-hand side of these constraints is simply a fixed number. For existence, we can appeal to the fixed-point theorem. ${ }^{2}$

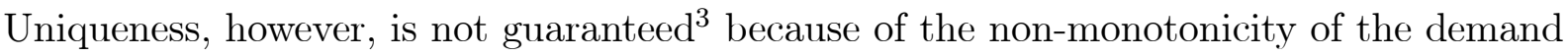
functions of the individual firms. Under the specific assumptions of this model therefore, equilibria exist and will each yield a distribution of observed $e t h_{k}$ where the wage profiles will exhibit compensating differentials for a taste for discrimination. The crucial assumption is that of no (long run) mobility restrictions of workers between firms and that there is some skill complementarity between white and ethnic minority workers in some firms. This assumption is supported by recent US empirical evidence (Carrington and Troske,

\footnotetext{
${ }^{2}$ The conditions for the fixed point theorem apply: $D^{E M}\left(w_{0}^{w h}, w_{0}^{e m}\right)$ and $D^{W H}\left(w_{0}^{w h}, w_{0}^{e m}\right)$ are continuous because the contribution of each firm is discontinuous only in a finite number of points with mass zero for market demand. Furthermore, $\lim _{w_{0}^{e m} \downarrow 0} D^{E M}\left(w_{0}^{w h}, w_{0}^{e m}\right)=\infty, \lim _{w_{0}^{w h} \downarrow 0} D^{W H}\left(w_{0}^{w h}, w_{0}^{e m}\right)=\infty$, $\lim _{w_{0}^{e m} \rightarrow \infty} D^{E M}\left(w_{0}^{w h}, w_{0}^{e m}\right)=0$ and $\lim _{w_{0}^{w h} \rightarrow \infty} D^{W H}\left(w_{0}^{w h}, w_{0}^{e m}\right)=0$. Hence there must be some finite point $\left\{w_{0}^{*, w h}, w_{0}^{*, e m}\right\}$ that satisfies both constraints.

${ }^{3}$ The problem in proving uniqueness is that the non-convexity of the cost function allows for the possibility at the individual firm that $\frac{\partial E M}{\partial w^{w h}}>-\frac{\partial E M}{\partial w^{e m}}>0$ and $\frac{\partial W H}{\partial w^{e m}}>-\frac{\partial W H}{\partial w^{w h}}>0$ for some range (for examples, see a previous footnote). This means that at the aggregate also, we can have that $\frac{\partial D^{E M}}{\partial w^{w h}}>$ $-\frac{\partial D^{E M}}{\partial w^{e m}}>0$ and $\frac{\partial D^{W H}}{\partial w^{e m}}>-\frac{\partial D^{W H}}{\partial w^{w h}}>0$. This in turn implies the possibility of multiple equilibria. In each of these equilibria the relative wage schedules must still be the same though.
} 
1998; Hellerstein and Neumark, 2004), who found that.black and white workers in the same firm often deploy very different skills.

Moreover, skill complementarity, which in our model reflects the firms where $\alpha_{k}$ is neither 1 nor 0 , is not just about white and ethnic minority workers performing different production tasks in the whole economy. Clearly, it would be wrong to agrue that some skills are 'only' performed by certain ethnic minoirty groups and not others. On the level of the whole economy, it is more the case that some groups are over-represented in some tasks. Even without aggregate skill differences, skill complementarities can still exist if there are local monopolies combined with high costs of moving elsewhere. In such circumstances, individuals are 'captured' in the sense that they have few options but to work for a particular organisation or industry. If there are then any local differences in the skill composition of the white and non-white labour force, that too can be seen as a situation of skill complementarities, even if for the whole country there are no such differences in skill composition between groups. Skill complementarities can also arise 'as if' in the situation where not skills but tastes over professions or jobs differ. Groups can for instance differ in their reluctance to perform menial jobs, even though they are 'objectively' equally skilled at doing them. The group less reluctant to perform such a task then in effect can be seen as having a comparative advantage in that skill. Note that there are many ways in which benefit systems and social practices can lead to such a situation. If, for instance, one group faces higher costs of working (e.g. higher loss of benefits, higher costs of childcare, higher opportunity costs) than that group will be absent from the lowest paid skill-markets. This is not because they lack those skills, but rather that they choose not to supply them. The group with lower costs of working will then supply those skills. These situations are (within our data) observationally equivalent to a situation where the skill composition between groups differs.

\section{Data and Variable Definitions}

The data we use is drawn from the Workplace Employee Relations Survey (WERS98) which was collected between October 1997 and July 1998. The survey covered all workplaces with 10 or more employees, located in Britain (England, Scotland and Wales) and 
engaged in activities within Sections D (Manufacturing) to O (Other Community, Social and Personal Services) of the 1992 Standard Industrial Classification. ${ }^{4}$ The survey covered both private and public sector workplaces. The sample of workplaces was selected through a process of stratified random sampling, with over-representation of larger workplaces and some industries using the Inter Departmental Business Register (IDBR). The main objective of WERS98 was to provide a substantial bank of data on the nature of workplace employment relations in Britain at the end of the 1990s (see Forth and Kirby, 2000, for additional details). This was the first survey of its kind in Britain.

The Survey took place at the workplace level and had three distinct components:

(i) Main management interview: Consisting of a face-to-face interview with the senior person at the workplace with day-to-day responsibility for industrial relations, employee relations or personnel matters - 2191 managers were interviewed, with a response rate of $80.4 \%$;

(ii) Survey of employees: Consisting of a self-completion questionnaire distributed to a random selection of up to 25 employees in each workplace - the questionnaire was distributed at 1880 workplaces (manager permitting), with a response rate of around $64 \%$;

(iii) Worker representative interview (where present): Consisting of a face-to-face interview with the most senior representative of the trade union with the largest number of members at the workplace, or with the most senior employee representative who sits on a workplace-level consultative committee - this occurred in 947 workplaces (manager permitting, and where relevant), with a response rate of $82 \%$.

Each of the three survey components can be linked by means of a unique workplace identifier. In this paper we use data from both the manager interview and the survey of employees. Our sample comprises 1764 workplaces and just over 24,000 employees,

\footnotetext{
${ }^{4}$ Workplaces whose main activity lied within the following Sections of the 1992 Standard Industrial Classification are not covered by WERS98: Agriculture, Hunting and Forestry (A), Fishing (B), Mining and Quarrying (C), Private households with employed persons (P) and Extra-territorial organizations and bodies $(\mathrm{Q})$.
} 
and given the focus of the paper is restricted to white employees only. ${ }^{5}$ A small number of observations (about 5\%) were deleted due to either missing responses from managers about key workplace characteristics or missing responses from employees about their job satisfaction or wages. A simple probit analysis suggests that these missing observations were reasonably random in observable characteristics. In this paper we use employees as our unit of analysis, but match to them important workplace characteristics.

The key variable of interest in this paper is the proportion of the workplace who are of ethnic minority origin, which we take as our measure for $e t h_{k}$. This information is collected from the main manager interview. ${ }^{6}$ In percentage terms, the responses range from $0 \%$ to $88 \%$, with the average workplace consisting of $4.7 \%$ (with a standard deviation of $9.1 \%$ ) of workers from ethnic minority groups. This reflects the $5.5 \%$ of the total population in Britain who are from the ethnic minorities. Around $41.7 \%$ of workplaces have no ethnic minority workers, a further $37.7 \%$ have between $1-5 \%$ of their workforce from the ethnic minorities, $9.1 \%$ have between $6-10 \%, 6.8 \%$ have between $11-30 \%$ and $4.7 \%$ have more than $30 \%$ of their workforce from the ethnic minorities.

The two dependent variables of interest are job satisfaction and wages, both of which are self-reported by employees in the employee questionnaire. The job satisfaction questions contained in the WERS98 are:

How satisfied are you with the following aspects of your job?

1. The amount of influence you have over your job.

2. The amount of pay you receive.

3 The sense of achieventent you get from your work.

${ }^{5}$ Although separate analyses investigating the effect of ethnic minority density at the workplace on the job satisfaction and wages of ethnic minority workers would be very interesting, the small sample of ethnic minority workers contained in the WERS (given that there was no over-sampling of ethnic minorities) prevents such a study.

${ }^{6}$ One clear limitation of the data, however, is that we only know the proportion of all ethnic minority workers and not the detailed breakdown by particular ethnic groups. The main ethnic minority groups in Britain are South Asian (Indian, Pakistani and Bangladeshi), Black Caribbean, Black African and Chinese. Therefore our estimates of the effect of ethnic minority density at the workplace on the job satisfaction and wages of white workers will be a weighted average since some white workers might prefer working with certain ethnic minority groups more than others. 
4. The respect you get from supervisors/managers.

The responses to each of these questions was reported on a 5-point scale ranging from Very Satisfied (1), Satisfied (2), Neither Satisfied or Dissatisfied (3), Dissatisfied (4) and Very Dissatisfied (5). Unfortunately, employees were not asked directly to evaluate their overall job satisfaction. Consequently, the job satisfaction measure we use is constructed by creating four binary variables taking the value of unity if the worker reports to be either Very Satisfied or Satisfied with a particular aspect of his or her job and zero otherwise. We then sum over the four binary variables to get an overall job satisfaction score that ranges between 0 (not satisfied with any aspects of the job) to 4 (Very Satisfied or Satisfied with all four job aspects).

Ideally we would have liked to have a more direct measure of job satisfaction. However, we would argue that a constructed index such as the one above is highly correlated with overall job satisfaction. To provide some evidence for this argument for British workers we can use data from the British Household Panel Study (BHPS) which collects information on a wider range of job satisfaction aspects including a direct question on overall job satisfaction. ${ }^{7}$ Whilst the four questions outlined above are not exactly the same as in the BHPS, we use the following four close counterparts: we have substituted (1) above with "satisfaction with being able to use your own initiative", (2) with "satisfaction with pay", (3) with "satisfaction with work itself" and (4) with "satisfaction with relations with boss". Summing these responses as done above, we find a very high correlation of 0.756 with overall reported job satisfaction.

Table 1 highlights the distribution of the constructed aggregate job satisfaction variable by gender. It is clear that the majority of workers in Britain report to be satisfied with the amount of influence they have over their job ( $57.9 \%$ of men, $60.2 \%$ of women), the sense of achievement they get from their work $(60.7 \%, 66.9 \%)$ and the respect they get from supervisors/managers $(54.2 \%, 62.45)$. In contrast, only $33.1 \%$ of males and $38.8 \%$ of females report satisfaction with the amount they get paid. Interestingly, each of these

\footnotetext{
${ }^{7}$ However, data from the BHPS can not form the basis for our analysis as no information on ethnic density at the workplace is collected nor does it contain any detailed information about workplace characteristics and working environment.
} 
figures is significantly higher for females than males, which concurs with a number of previous studies that have found that women generally report to be happier at work than males (Clark, 1997). This gender differential is also clearly reflected in the average satisfaction score of 2.06 for males and 2.28 for females.

The wage information collected from respondents of the employee questionnaire relates to the following question:

"How much do you get paid for your job here, before tax and other deductions are taken out? If your pay changes before tax from week to week because of overtime, or because you work different hours each week, think about what you earn on average".

One limitation with this question, however, is that respondents were not free to report their wage exactly, but rather asked to report it within 12 bands. Figure 1 shows the distribution of wages by gender. As expected, the male wage distribution lies substantially to the right of the female distribution, which partly reflects the greater percentage of females than males who are employed on a part-time basis. In the empirical wage models we specifically control for the number of working hours.

To get a first feel for the relationship between ethnic minority density at the workplace and job satisfaction and wages, Tables 2 and 3, respectively, provide some simple crosstabulations of these variables. To aid this we have split the proportion of ethnic minorities at the workplace into three categories:- no ethnic minorities at the workplace; a proportion of $0.01-0.24$ of workers from ethnic minorities; and a greater than 0.24 proportion of ethnic minority workers. We similarly divide wages into four broad bands:- Very Low, Low, Medium and High. For both males and females there is some suggestion that average job satisfaction for white workers is lower in workplaces that have a high ethnic minority density. However, the 'raw' relationship between ethnic minority density and wages is less clear. There is some evidence suggesting that the percentage of whites earning high wages (i.e. $>£ 360$ per week) is greater in workplaces which have a high density of ethnic minority workers. Similarly, very high ethnic minority density workplaces have significantly fewer workers earning less than $£ 141$ per week than workplaces with no ethnic minority workers. 
Overall, these relationships tentatively appear to be consistent with white workers having a taste for discrimination which is compensated by higher wages in high ethnic minority density workplaces.

\section{Econometric Modelling}

\subsection{Models}

Following the seminal work of Hamermesh (1977), Freeman (1978) and Borjas (1979), a growing number of economics studies have empirically investigated the determinants of job satisfaction, with a particular focus on the role of wages (both absolute and relative), working hours, firm size and trade union density (e.g. Idson, 1990; Gordon and Denisi, 1995; Clark, 1996; Clark and Oswald, 1996; Laband and Lentz, 1998; Hamermesh, 2001; Shields and Ward, 2001; Heywood et al., 2002; Booth et al., 2002; van Praag et al., 2003). These studies have covered the workforce as a whole (e.g. Clark, 1996) and individual professional groups such as academics (e.g. Ward and Sloane, 2000), nurses (e.g. Shields and Ward, 2001) and lawyers (e.g. Laband and Lentz, 1998). However, we are unaware of any study that has attempted to use matched employer-employee data to establish the effect on job satisfaction of working alongside co-workers from different racial or ethnic groups.

With reference to the empirical specifications used in these studies, and given the ordinal nature of the job satisfaction variable combined with the matched employer-employee nature of the data, we fit the following random effects ordered probit job satisfaction equation to the data. ${ }^{8}$ Here $J S_{i k}^{*}$ denotes the latent job satisfaction of white individual $i$ in workplace $k$ and $J S_{i k}$ the categorical observed value:

$$
J S_{i k}^{*}=x_{i k} \beta_{1}+\delta_{1}^{*} e t h_{k}+\ln \left(w_{i k}\right)+v_{k}+\epsilon_{i}
$$

\footnotetext{
${ }^{8}$ Note that we are not able to implement a fixed effect estimator since we do not observe time variation in ethnic density at the workplace. However, we do believe that the extra individual and workplace-specific control variables we include in the models comprehensively capture heterogeneity in worker skills, job quality and the general working environment (Hirsch and McPherson, 2004).
} 


$$
J S_{i k}=n \Leftrightarrow \lambda_{n-1}<J S_{i k}^{*} \leq \lambda_{n}
$$

where $x_{i k}$ is a set of variables including ethnic minority density, $\ln \left(w_{i k}\right)$ is $\log$ wages, $\lambda_{n}$ are cut-off points increasing in $\mathrm{n}, v_{k}$ is a normally distributed random effect of the workplace, and $\epsilon_{i}$ is an individual normally distributed random error. The categorical answers run from $\mathrm{n}=0$ to $\mathrm{n}=4$. As normalisations, we put $\lambda_{-1}=0, \lambda_{4}=\infty$, and $\operatorname{Var}\left(\epsilon_{i}\right)=1$. Note that this normalisation is not trivial in the sense that an observationally equivalent model can be run with $\operatorname{Var}\left(\epsilon_{i}\right)=\sigma^{2}$ in which all the estimated coefficient would be a factor $\sigma$ higher. Hence, $\delta_{1}^{*}$ only identifies $\frac{\delta_{1}}{\sigma}$, which means a positive value for the estimated $\delta_{1}^{*}$ only implies a positive $\delta_{1}$. The equation is estimated using Gaussian quadrature.

Considering the structural interpretation of this equation, we should bare in mind that our extended theoretical model only allows for one endogenous workplace characteristic, namely ethnic minority density. This means that in order to interpret $\beta$ as the structural estimates of the full model, we would have to interpret the coefficients of any other workplace specific variable as picking up some (otherwise unobserved) individual characteristic such as worker quality. This consideration does not hold for the partial equilibrium model where we can directly interpret the findings on $\delta_{1}^{*}$ as giving direct evidence on discriminatory tastes.

We simultaneously estimate an interval wage model with latent log-wage $\ln w_{i k}^{*}$ equal to:

$$
\begin{aligned}
\ln w_{i k}^{*} & =x_{i k} \beta_{2}+\delta_{1} e t h_{k}+\epsilon_{k}^{w}+\epsilon_{i}^{w} \\
w_{i k} & =n \Leftrightarrow \kappa_{n-1}<w_{i k}^{*} \leq \kappa_{n}
\end{aligned}
$$

where $\delta_{1}$ refers to the full model and $\epsilon_{i}^{w}$ and $\epsilon_{k}^{w}$ are assumed to be independently normally distributed. Given the banded characteristics of the wage information, this model is estimated with standard interval-regression techniques, whereby the only peculiarity is that the error term has two components instead of one. Again, this equation can be directly interpreted in the partial equilibrium framework. In order to interpret it as an estimation of the fully structural model, we would have to interpret the effect of each $x_{i k}$ as due to the effect of fixed individual characteristics, such as worker quality. 


\subsection{Explanatory variables}

For both the job satisfaction and wage empirical models we perform a four-step sensitivity analysis by successively increasing the number of variables in $x_{i k}$. Firstly, we fit the models including only direct personal characteristics and basic job characteristics as covariates (termed the Basic specification). These are: age, marital status, dependant children, health, highest qualification, broad occupation group, log weekly wages (calculated at the mid-points of the bands), log working hours, whether the employee works from home, temporary job, trade union membership and job tenure. Additionally, we control for the unemployment / vacancy rate (in the travel-to-work area) and regional house prices (which we have mapped into the data from external government sources). Secondly, we then test the robustness of our main results by adding a number of individual workrelated characteristics to control for as much individual heterogeneity as possible (termed Extended 1). These variables, interpreted as proxies for worker quality, are whether or not the employee agrees that his or her job requires one to work very hard or does not have enough time to get his or her job done, how many days of off-the-job employer-funded training the worker has received in the last 12 months and whether the worker reports that he or she is often asked for advice about workplace practices by supervisors/managers. All of the variables identified so far are taken from information recorded during the employee interview.

Thirdly, we extend these models using the unique matched employee-employer feature of WERS98, by adding a wide range of workplace level information to comprehensively capture various job circumstances and to control for workplace quality (referred to as Extended 2). The variables, taken from the manager interview, include the percentage of employees working part-time or who are female; whether an equal opportunities policy is in force; trade union density; the number of employees and whether the workplace is part of a multi-plant firm; broad industrial classification and whether the owner-manager is present. In addition, we control for a number of recent workplace history aspects (all relating to the previous 12 months). These are whether there has been difficulties filling vacancies; the percentages of vacancies filled internally; of full-time employees who 
received off-the-job employer-funded training; of workdays lost due to absence and of workers who had a work-related injury. Furthermore, we include two variables to capture aspects of the pay distribution, namely, the percentages of employees earning less than $£ 9,000$ per year and more than $£ 29,000$ per year. We believe that in sum these variables are likely to capture the majority of the heterogeneity in workplace quality and working environment.

Given our interest in providing further insights into the mechanism by which discrimination tastes exist, our final specification (Extended 3), additionally includes variables that can be interpreted as 'intervening variables'. These are whether or not a white worker feels that his or her job is secure (taken from the employee questionnaire) and whether there has been reported racial tension or complaints about working conditions at the workplace in the 12 months (taken from the manager interview). The first of these variables allows us to explore the perceived wisdom that it is mainly the effect of ethnic minority workers on feelings of job-insecurity amongst white workers that generates a taste for discrimination. More generally, these additional estimates will be informative about the mechanisms by which race relations operate at the British workplace.

Importantly, in each of the four empirical specifications we also control for regional house prices and unemployment / vacancy rates, in the travel-to-work area, in order to allow for differences in the cost of living and outside employment opportunities across Britain. Moreover, initial pooling tests suggest that it would be inappropriate to combine both males and females into single models, thus we perform separate job satisfaction and wage analyses by gender.

\section{Empirical Results}

The results from the four specifications of the job satisfaction workplace random effects ordered probit model for white males and females are shown, respectively, in Tables A1 and A2. Given the difficulty in interpreting the quantitative effect of an explanatory variable on job satisfaction from these non-linear models we also provide (for brevity, only for the Extended 3 specification) the associated Marginal Effect (ME), calculated at the means of the other explanatory variables and setting the random effects term to be 
equal to zero. The corresponding results from the rando effects interval wage regressions are presented in Tables A3 and A4.

\subsection{The effect of ethnic minority density on job satisfaction and wages}

In order to aid the discussion of the importance of ethnic minority density at the workplace, we also report the parameter estimates for ethnic minority density for all specifications of the job satisfaction and wage models and present them in Table 4.

In our most important result, we find robust evidence that the effect of ethnic minority density on job satisfaction is negative for all specifications of the job satisfaction model for both males and females. ${ }^{9}$ However, there is a clear difference in the magnitude of this effect by gender. Looking first at the results for males, we see that in the Basic specification, with only individual characteristics as controls, the effect is -0.629 . The wage effect is largest here, with a white male having to be compensated by around $19 \%$ higher wages to work in a workplace where all of his co-workers are from ethnic minorities, compared to a workplace with no ethnic minority co-workers. When we add 'job-involvement' variables (Extended 1), the negative effect of ethnic minority density on job satisfaction increases slightly, whereas there is a small decrease in the positive effect of ethnic minority density on wages (to $16 \%$ ). A comparison of the log likelihood values also indicates that the fit of the models increases substantially. This supports the notion that 'job-involvement' variables capture a great deal of individual variation that is important in explaining both wages and job satisfaction. Since they can be correlated with, but are not reasonably caused by, ethnic minority density at the workplace, it is clearly important to control for them. When we further add a host of workplace characteristics (Extended 2), the importance of ethnic minority density drops both for job satisfaction (to -0.532) and wages (to 12\%). Given that these comprehensive workplace characteristics pick up a great deal of individual and workplace quality information (as evidenced by the change

\footnotetext{
${ }^{9}$ Just for information, a simple bivariate model of job satisfaction, where job satisfaction is regressed only on ethnic density, finds a coefficient of $-0.307(t$-stat $=1.88)$ for females and $-0.415(t$-stat $=2.16)$ for males. Bivariate wage models find a coefficient of $0.475(t$-stat $=3.29)$ and $1.016(t$-stat $=5.58)$, respectively.
} 
in log-likelihoods), we view this specification as yielding the most reliable estimate of the total effect of ethnic minority density on white male workers.

Turning to our final specification (Extended 3), where we include variables that can be viewed as 'intervening', we surprisingly find no change in the effect of ethnic minority density on either job satisfaction or wages (and little improvement in log-likelihoods). Although job-insecurity indeed is an important variable for job satisfaction, it is apparently not capturing any of the effect of ethnic minority density. This is an interesting finding which to some extent supports a number of recent studies which have found no significant effect of immigration on the actual employment prospects, or the perceptions of job security, amongst the majority population (see Borjas, 1999, for a general review; and Dustmann and Preston, 2002, for British evidence).

When we turn to females, qualitatively the same story applies. Again job-involvement variables capture a great deal of individual heterogeneity but do not alter the ethnic minority density effect. Workplace characteristics capture a lot of the effect of ethnic minority density though, both in wages and in job satisfaction. The absolute changes in the effects of ethnic minority density, when we include workplace characteristics, are the same for males as for females. In this favoured specification, the signs are the same as for males, but the effects are much smaller and statistically insignificant. Hence, insofar as ethnic minority density is a negative job-amenity, it appears to be significantly so for white males but not for white females. Furthermore, when we add 'intervening' variables, there is no substantial change in the effect of ethnic minority density, implying that job insecurity and racial tensions are not actually important intervening variables for the effect of ethnic minority density amongst white female employees.

In our favoured specification (Extended 2 model), the effect of ethnic minority density on job satisfaction is -0.532 for males and -0.215 for females. On a 0 to 4 scale, this is quite a large effect, and indeed the ME's for ethnic minority density are amongst the largest of the entire set of variables. The wage effects of ethnic minority density for this specification are $12 \%$ for males and $7 \%$ for females. ${ }^{10}$ If this wage effect truly reflects

\footnotetext{
${ }^{10}$ Interestingly, these compensating wage differentials are very close to the hourly wage gaps, between white and ethnic minority employees, found using WERS 98 by Pudney and Theodoropoulos (2003),
} 
the effect of ethnic minority density as a job amenity, this would mean that an absolute change of 0.1 in latent job satisfaction is roughly worth $2.5 \%$ in wages.

Apart from the robustness checks presented above, we have also fitted several model specifications that allowed for differential effects for different age and education groups. Importantly, the estimated effects of ethnic minority density were found to be similar across age groups, education groups, and industries. However, significance was affected by the reduction in sample size. We have also examined the robustness of these results to two alternative derivations of overall job satisfaction, and found that our main results are qualitatively unchanged. For example, instead of collapsing the 5-point responses to the four job satisfaction questions into binary variables (i.e. 1= very satisfied or satisfied), and then summing over the resulting four variables, we simply aggregrated the raw responses leading to an overall job satisfaction variable ranging from 0 to 16.

\subsection{The general determinants of job satisfaction}

Overall, our results comply favourably with the findings of the recent job satisfaction literature using British data (see, for example, Clark, 1996; Shields and Ward, 2001). We too find that job satisfaction in increasing with wages, and decreasing with hours of work, for both men and women. For males, we find a U-shaped relationship between age and job satisfaction but, for females, we find that job satisfaction is clearly increasing with age. However, the results concerning our wage distribution measures show little evidence of a relative wage effect. For both males and females, higher levels of education are associated with reduced job satisfaction, whilst individuals in managerial and professional occupations clearly have the highest job satisfaction levels. Interestingly, job satisfaction is higher for workers who report that their job requires them to work very hard, for those who have received employer-funded off-the-job training in the last year and for those who are often asked advice from their supervisors/managers. Individuals who report that they do not have enough time to get their job done have lower job satisfaction levels.

Turning to workplace characteristics, we find that job satisfaction is higher at worknamely $13 \%$ amongst males and $6 \%$ amongst females. The male finding also closely mirrors the $11 \%$ male wage differential found for the UK in the 1990s by Blackaby et al. $(1998,2002)$. 
places that have a large proportion working part-time, but the gender composition of the workplace is not a significant predictor of job satisfaction. For males we find that employees in small workplaces report higher job satisfaction levels whereas females job satisfaction levels are significantly associated with the presence of an equal opportunities policy and trade union density. Industry is also an important determinant of job satisfaction in Britain, even after controlling for many other workplace characteristics. Interestingly, the percentage of workdays lost due to absence is not a significant predictor of job satisfaction at the workplace.

Turning to our intervening variables, which might explain the reasons for tastes for discrimination arising, we find that feelings of job insecurity significantly reduce job satisfaction for both males and females. However, we find little evidence that working in a workplace that has, according to the manager, experienced racial tension, discrimination or bad working conditions in the last 12 months, is associated with reported job satisfaction levels. Finally, it is clearly the case that there exist unobserved workplacespecific characteristics that impact on job satisfaction, even after extensively controlling for workplace characteristics. This latter finding reinforces the usefulness of matched employee-employer survey data when investigating the determinants of job satisfaction.

\subsection{The determinant of wages}

Finally, we will briefly discuss the auxiliary results from the wage equations. As expected, we find a n-shaped age profile, with wages being highest in the age range 40-49 for both genders. Education is clearly important, as is marital status, having dependant children and health. Occupation is a major predictor of wages, with wages being highest for managers and professionals. There is the expected tenure profile, and weekly wages are increasing with hours worked. Working in a temporary job is associated with lower wages, whilst there are positive wage effects of working at home and being a member of a trade union. Wages are higher in regions where house prices are high, capturing differences in the cost of living across Britain. There is also some evidence for males that wages are lower in travel-to-work areas that have higher unemployment / vacancy rates.

Those who undertook training in the last 12 months report higher wages, as do those 
workers who report that they are often asked by their supervisor/manager for advice about workplace practices. For males only, wages are lower in workplaces that have a high density of part-time workers and higher in workplaces that employ a high percentage of female workers. Trade union density is clearly associated with higher wages, but wages are only higher in larger workplaces for males. Industry is an important predictor of wages, with workers in financial services earning the most. For females, wages are higher in single workplace firms and lower in workplaces that have had problems filling vacancies in the last 12 months. For males, there is some evidence indicating that wages are higher in workplaces that suffer from a lot of work-related injuries, possibly capturing a compensating differential effect. Lastly, the workplace wage distribution variables have the expected effect, with an individual's wages being higher in workplaces with a higher percentage of workers earning more than $£ 29,000$ per year.

\subsection{Limitations}

Before we conclude it is important to note a number of robustness issues and limitations of our analyses. In particular, for the following reasons we believe that the main results should be viewed as lower bounds to the actual importance of workplace ethnic density to white employees' job satisfaction and wages:

1. Directly paying employees more for the same job is not the only way in which workers can be compensated for job amenities. It is possible that one form of compensation for job amenities is to assign someone to a higher occupation than would otherwise be warranted on the basis of their human capital characteristics. Similarly, negative amenities can be partially compensated by greater job security and hence higher wages via longer tenure. We found that, for both occupation and tenure, if they are omitted from the set of explanatory variables the effects of ethnic density increase. However, fitting separate models that excluded occupations and tenure only increased the wage effects of ethnic density by a factor of about 1.2.

2. In an ideal analysis we would utilise a natural experiment or exogenous sorting of workers into different workplaces to identify the causal effect of ethnic density on 
white employees job satisfaction and wages. One possible source of such exogenous variation would result from government imposed positive affirmative action (or positive discrimination in favour of certain ethnic minority groups) in selected occupations or industries. However, no such policy has been introduced in Britain. Consequently, if there is heterogeneity in the extent to which white workers have a taste or preference against working alongside ethnic minority co-workers, then in our frictionless theoretical model there will be assortative matching i.e. white employees who have the least dislike of ethnic minority co-workers will be observed at workplaces which have most ethnic minority co-workers (because their required compensation is the lowest). This means that our estimated effect of ethnic co-workers might be lower than the latent effect of ethnic co-workers on a random non-ethnic individual. However, some support for the robustness of our results come from Carrington and Troske (1998), who document evidence that the inter-firm distribution of black and white workers is close to that implied by random assignment in the US.

3. If the lower unobserved quality white workers are more likely to be found in workplaces with higher ethnic minority density, then this would bias our wage results downward (Hwang et al., 1992).

4. If there is measurement error in the ethnic minority density at the workplace variable, then this will bias our results towards zero. A potential cause of this is that ethnic minority density is self-reported by the manager who may have imperfect information, particularly in a very large firm. A related limitation of our analysis is that we only have a measure for overall ethnic density at the workplace, so we are not able to establish if white workers in Britain have a particularly strong taste against working with certain ethnic minority groups but are indifferent with respect to other groups. This would be an interesting question for future research.

\section{Conclusions}

Becker $(1957,1971)$ proposed an important theory to explain the existence of racial discrimination in the labour market, based on the idea that the dominant groups of workers 
(i.e. whites) have a taste or preference against working alongside minority groups (i.e. blacks). However, relative to the other major competing theories of discrimination, this theory has had only limited empirical testing (see Altonji and Blank, 1999). An important exception is Chiswick (1973), who found using state-level variation in the US, that white workers of a given skill level, needed to receive compensation in the form of higher weekly wages if they worked with non-whites. In this paper we contribute to this literature by using recently matched employer-employee data from Britain to investigate if white workers are observed to have lower job satisfaction the higher the ethnic density in the workplace, and whether white workers need to be compensated by higher wages for working alongside ethnic minority co-workers. To support the robustness of our empirical results we have been able, given the high-quality of the data, to control comprehensively for heterogeneity in individuals characteristics, job quality and general work environment. To support our empirical analyses we have also contributed to the theoretical modelling of employee-based discrimination by developing a structural model that incorporates both individual and firm heterogeneity.

We have found clear evidence in support for these two predictions. Importantly, job satisfaction is found to be significantly lower for white workers in workplaces with a high density of ethnic minorities, and white male workers require a wage premium of around $12 \%$ to compensate them for a move from a workplace with no ethnic minority co-workers to one with only ethnic minority co-workers. We believe that the magnitude of this estimate is reasonable, and is consistent with a structural model of worker allocation in the presence of a taste for discrimination amongst employees. For females, the effects are smaller and statistically insignificant, with a necessary compensating differential of about 7\%. This concurs with earlier findings for the US by Carrington and Troske (1998) that only a small amount of compensation is needed for females. The finding of racial prejudice in Britain, particularly for males, is supported by the recent findings of Dustmann and Preston (2001), for the population generally, and by Shields and Wheatley Price (2002a, 2002b), who examine the reported incidence of racial harassment at the workplace. Strikingly $38 \%$ of the population sample reported being at least a little prejudiced against people of other races whilst over half of ethnic minority nurses claim to have been the vic- 
tim of racially-motivated abuse from co-workers. Given the current high-profile debate in Britain and elsewhere about the costs and benefits of increased immigration, an additional important finding is that the taste for discrimination does not appear to operate through greater job insecurity for white workers. This is consistent with the international literature that finds that immigration has little impact on natives employment opportunities or wages (see, Borjas, 1999).

Finally, we should note some limitations of our analysis. If anything, we have argued that due to data limitations and the lack of exogenous sorting of white employees into workplace with different ethnic minority densities, our estimates of the required compensation required by white workers employed alongside ethnic minority co-workers, are likely to be lower bounds. Moreover, an alternative explanation consistent with our results is that white workers and ethnic minority co-workers simply find it hard to get along because of language or other cultural barriers. To assign blame to a white worker who prefers to work with people he or she might not get along with easily is not necessarily warranted. Similarly, there may be a taste for discrimination amongst ethnic minority employees, although we have been unable to investigate this possibility with our data. Future research may shed more light on this topic and provide further confirmation of the presence of employee discrimination at the workplace.

\section{References}

1. Abowd, J. and Kramarz, F. (1999). The analysis of labor markets using matched employer-employee data. Chapter 40 in Ashenfelter, O. and Card, D. (eds). Handbook of Labor Economics, Volume 3B. North-Holland.

2. Acemoglu, D. and Pischke, J. (1998). Why do firms train? Theory and evidence. Quarterly Journal of Economics, 113, pp. 79-119.

3. Akerlof, G., and Kranton, R. (2000). Economics and identity. Quarterly Journal of Economics, 115, pp. 715-753.

4. Altonji, J. and Blank, R. (1999). Race and gender in the labor market. In Ashenfelter, O. and Card, D. (eds.), Handbook of Labor Economics, volume 3: Elsevier 
Science.

5. Altonji, J. and Pierret, C. (2001). Employer learning and statistical discrimination. Quarterly Journal of Economics, 116, pp. 313-350.

6. Arrow, K. (1973). The theory of discrimination, in Ashenfelter, O. Rees, A. (eds.), Discrimination in Labor Markets: Princeton: Princeton University Press.

7. Arrow, K. (1998). What has economics to say about racial discrimination. Journal of Economic Perspectives, 12, pp. 91-100.

8. Bayard, K., Hellerstein, J., Neumark, D. and Troske, K. (2003). New evidence on sex segregation and sex differences in wages from matched employee-employer data. Journal of Labor Economics, 21, pp. 887-922.

9. Becker, G. (1957). The Economics of Discrimination. Chicago: University of Chicago Press.

10. Becker, G. (1971). The Economics of Discrimination (2nd edition). Chicago: University of Chicago Press.

11. Becker, G. (1991). A Treatise on the Family. Cambridge, Mass, Harvard University Press.

12. Blackaby, D., Clark, K., Leslie, D. and Murphy, P. (1994). Black-white male earnings and employment prospects in the 1970s and 1980s: evidence for Britain. Economics Letters, 46, pp.273-279

13. Blackaby, D., Drinkwater, S., Leslie, D. and Murphy, P. (1997). A picture of male and female unemployment among Britain's ethnic minorities. Scottish Journal of Political Economy, 44, pp.182-197.

14. Blackaby, D., Leslie, D., Murphy, P. and O'Leary, N. (1998). The ethnic wage gap and employment differentials in the 1990s : Evidence for Britain. Economics Letters, 58, pp. $97-103$. 
15. Blackaby, D., Leslie, D., Murphy, P. and O'Leary, N. (2002). White/ethnic minority earnings and employment differentials in Britain: evidence from the LFS. Oxford Economic Papers, 54, pp. 270-297.

16. Booth, A., Francesconi, M. and Frank, J. (2002). Temporary jobs: stepping stones or dead ends? Economic Journal, 112, pp. 184-213.

17. Borjas, G. (1979). Job satisfaction, wages and unions. Journal of Human Resources, XIV, pp. 21-40.

18. Borjas, G. (1999). The economic analysis of immigration. In Ashenfelter, O. and Card, D. (eds.), Handbook of Labor Economics, volume 3: Elsevier Science.

19. Breen, R. and Garcia, P. (2002). Bayesian learning and gender segregation. Journal of Labor Economics, 20, pp. 899-922.

20. Cain, G. (1986). The economic analysis of labor market discrimination: a survey. Chapter 13, Handbook of Labor Economics, 1, pp. 693-785.

21. Carrington, W. and Troske, K. (1998). Interfirm segregation and the black/white wage gap. Journal of Labour Economics, 16, pp. 231-260.

22. Cassirer, N. (1996). Race composition and earnings: effects by race, region and gender. Social Science Research, 24, pp. 375-399.

23. Chiswick, B.R. (1973). Racial discrimination in the labor market: a test of alternative hypotheses. The Journal of Political Economy, 81, pp. 1330-1352.

24. Clark, A. (1996). Job satisfaction in Britain. British Journal of Industrial Relations, 34, pp. 189-218.

25. Clark, A. (1997). Job satisfaction and gender: why are women so happy at work. Labour Economics, 4, pp. 341-372.

26. Clark, A. and Oswald, A. (1996). Satisfaction and comparison income. Journal of Public Economics, 61, pp. 359-382. 
27. Coate, S. and Loury, G.C. (1993). Will affirmative-action policies eliminate negative stereotypes? American Economic Review, 83, pp. 1220-1240.

28. Darity, W. and Mason, P. (1998). Evidence on discrimination in employment: Codes of color, codes of gender. Journal of Economic Perspectives, 12, pp. 63-90.

29. Dustmann, C. and Fabri, F. (2003). Language proficiency and labour market performance of immigrants in the UK. Economic Journal, 113, pp.695-717.

30. Dustmann, C. and Preston, I. (2001). Attitudes to ethnic minorities, ethnic context and location decisions. Economic Journal, 111, pp. 353-373.

31. Dustmann, C. and Preston, I. (2002). Racial and economic factors in attitiudes to immigration. University College London, mimeo.

32. Farmer, A. and Terell, D. (1996). Discrimination, Beyesian updating of employers' beliefs, and human capital accumulation. Economic Inquiry, 34, pp. 204-219.

33. Fershtman, C. and Gneezy, U. (2001), 'Discrimination in a segmented society: en experimental approach', Quarterly Journal of Economics, 116, pp. 351-77.

34. Forth, J. and Kirby, S. (2000). Guide to the Analysis of the Workplace Employee Relations Survey 1998. NIESR: London. WERS98 Dissemination Service (www.niesr.ac.uk/niesr/wers98/).

35. Freeman, R. (1978). Job satisfaction as an economic variable. American Economic Review, 68, pp. 135-141.

36. Frijters, P. (1998). Discrimination and job-uncertainty. Journal of Economic Behaviour and Organisation, 36, pp. 433-446

37. Gordon, M. and Denisi, A. (1995). A re-examination of the relationship between union membership and job satisfaction. Industrial and Labor Relations Review, 48, pp. $222-236$. 
38. Haltiwanger, J., Lane, J., Spletzer, J., Theeuwes, J. and Troske, K. (1999). The Creation and Analysis of Employer and Employee Matched Data. Amsterdam: NorthHolland.

39. Hamermesh, D. (1977). Economic aspects of job satisfaction. In Ashenfleter, O. and Oates, W. (eds.) Essays in Labor Market Analysis. John Wiley: New York.

40. Hamermesh, D. (1999). Leeping into the future of labor economics: The research potential of linking employer and employee data. Labour Economics, 6, pp. 25-41.

41. Hamermesh, D. (2001). The changing distribution of job satisfaction. Journal of Human Resources, 36, pp. 1-30.

42. Heckman, J. (1998). Detecting discrimination. Journal of Economic Perspectives, 12, pp. 101-116.

43. Hellerstein, J. and Neumark, D. (2002). Ethnicity, language, and workplace segregation: Evidence from a new matched employer-employee data set. NBER Working Paper no. 9037: Cambridge, MA.

44. Hellerstein, J. and Neumark, D. (2004). Workplace segregation in the United States: Race, Ethnicity, and Skill. Working Paper no. 2004.05, Public Policy Institute of California.

45. Heywood, J.S., Siebert, W.S. and Wei, X. (2002). Worker sorting and job satisfaction: the case of union and government jobs. Journal of Human Resources, 55, pp. 595-609.

46. Hirsch, B. and McPherson, D. (2004). Wages, sorting on skill, and the racial composition of jobs. Journal of Labor Economics, forthcoming.

47. Hwang, H., Reed, W.R. and Hubbard, C. (1992). Compensating wage differentials and unobserved productivity. Journal of Political Economy, 100, pp. 835-858.

48. Idson, T. (1990). Establishment size, job satisfaction and the structure of work. Applied Economics, 22, pp. 1007-1018. 
49. Knowles, J., Persico, N., Todd, P. (2001). Racial bias in motor vehicle searches: theory and evidence. Journal of Political Economy, 109, pp. 203-29.

50. Kremer, M. (1993). The O-ring theory of economic development. Quarterly Journal of Economics, pp. 551-575.

51. Laband, D. and Lentz, B. (1998). The effects of sexual harassment on job satisfaction, earnings and turnover among female lawyers. Industrial and Labor Relations Review, 51, pp. 594-607.

52. Lang, K. (1986). A language theory of discrimination. Quarterly Journal of Economics, 101, pp. 363-382.

53. Lazear, E. and Rosen, S. (1990). Male-female wage differentials in job ladders. Journal of Labour Economics, 8, pp. S106-S123.

54. Neal, D.A. and Johnson, W.R. (1996). The role of pre-market factors in Black-White wage differences, Journal of Political Economy, 104, pp. 869-895.

55. Neumark, D. (1999). Wage differentials by race and sex: The roles of taste discrimination and labor market information. Industrial Relations, 38, pp. 414-445.

56. Phelps, E.S. (1972). The statistical theory of racism and sexism. American Economic Review, 62, pp. 659-661.

57. Polachek, S. (1995). Human capital and the gender earnings gap, in Kuiper, E. and Sap, J. (eds.), Out of the margin. Feminist perspectives on economics, London: Routledge, pp. 61- 79.

58. van Praag, B., Frijters P., and Ferreri Carbonell, A. (2003). The anatomy of subjective well-being. Journal of Economic Behavior and Organization, 51, pp. 29-49.

59. Pudney, S. and Shields, M. (2000a). Gender and racial discrimination in pay and promotion for NHS nurses. Oxford Bulletin of Economics and Statistics, 62, pp. 801-836. 
60. Pudney, S. and Shields, M. (2000b). Gender, race, pay and promotion in the British nursing profession: Estimation of a generalized ordered probit model. Journal of Applied Econometrics, 15, pp. 367-399.

61. Pudney, S. and Theodoropoulos, N. (2003). Firm-specific gender and ethnicity pay differentials in Britain. University of Leicester, mimeo.

62. Riach, P.A. and Rich, J. (2002). Field experiments of discrimination in the market place. Economic Journal, 112, pp. F480-F518.

63. Rosén, A. (1997). An equilibrium search-matching model of discrimination. European Economic Review, 41, pp. 1569-1588.

64. Shields, M. and Ward, M. (2001). Improving nurse retention in the National Health Service in England: The impact of job satisfaction on intentions to quit. Journal of Health Economics, 20, pp. 677-701.

65. Shields, M. and Wheatley Price, S. (2002a).The determinants of racial harassment at the workplace: evidence from the NHS nursing profession. British Journal of Industrial Relations, 40, pp. 1-21.

66. Shields, M. and Wheatley Price, S. (2002b). Racial harassment, job satisfaction and intentions to quit: Evidence from the British nursing profession. Economica, 69, pp. $295-326$.

67. Stewart, M. (1983). Racial discrimination and occupational attainment in Britain. Economic Journal, 93, pp. 521-543.

68. Tzannatos, Z. (1988). The long-run effects of the sex integration of the British labour market. Journal of Economic Studies, 15, pp.5-18.

69. Ward, M. and Sloane, P. (2000). Non-pecuniary advantages versus pecuniary disadvantages; job satisfaction among male and female academics in Scottish Universities. Scottish Journal of Political Economy, 47, pp. 273-303. 
TABLE 1: The Distribution of Job Satisfaction by Gender

\begin{tabular}{lcc}
\hline Percentage & MALES & FEMALES \\
\hline \multirow{2}{*}{ Job Satisfaction Aspect } & & \\
& & \\
Amount of influence $(1,0)$ & 57.9 & 60.2 \\
& $(0.46)$ & $(0.46)$ \\
Amount of pay $(1,0)$ & 33.1 & 38.8 \\
& $(0.44)$ & $(0.45)$ \\
Sense of achievement $(1,0)$ & 60.7 & 66.9 \\
& $(0.45)$ & $(0.44)$ \\
Respect from supervisor/manager $(1,0)$ & 54.2 & 62.4 \\
& $(0.46)$ & $(0.45)$ \\
\hline Average overall satisfaction score $(0-4)$ & 2.06 & 2.28 \\
& $(0.01)$ & $(0.01)$ \\
\hline \hline
\end{tabular}

Note: Standard error of mean value shown in parentheses.

FIGURE 1: The Distribution of Wages by Gender

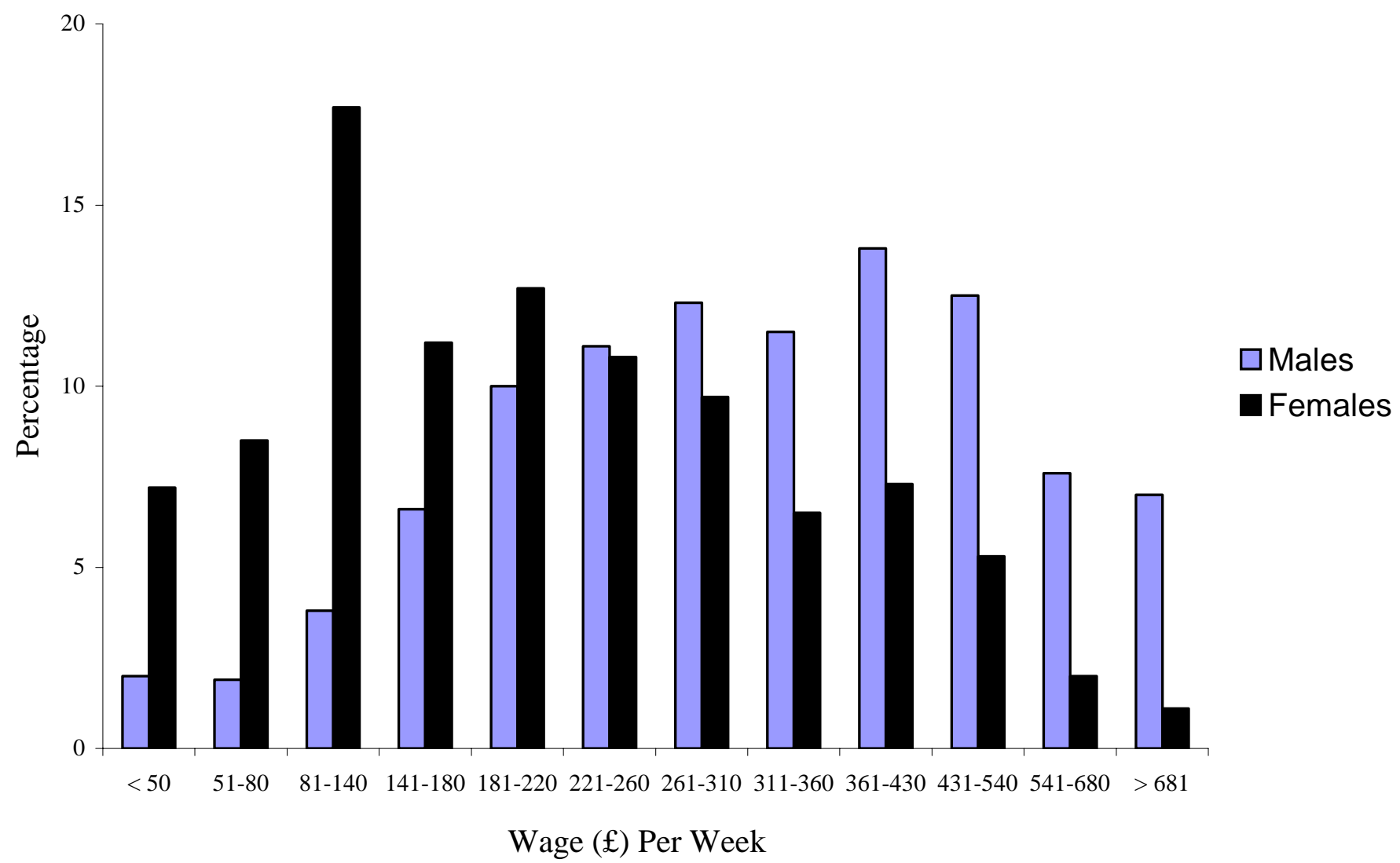


TABLE 2: Average Job Satisfaction by Workplace Ethnic Density

\begin{tabular}{l|c|c}
\hline Percentage & MALES & FEMALES \\
\hline Ethnic Density & & 2.14 \\
$>$ 25\% of employees from ethnic minorities & 1.92 & $(0.06)$ \\
& $(0.07)$ & 2.22 \\
$1-24 \%$ & 2.05 & $(0.02)$ \\
0\% of employees from ethnic minorities & $(0.02)$ & 2.37 \\
& 2.09 & $(0.02)$
\end{tabular}

Note: Standard error of mean value shown in parentheses.

TABLE 3: Wage Distribution by Workplace Ethnic Density

\begin{tabular}{l|cccc|cccc}
\hline Percentage & \multicolumn{5}{|c|}{ MALES } & \multicolumn{5}{c}{ FEMALES } \\
\hline & L & M1 & M2 & H & L & M1 & M2 & H \\
\hline Ethnic Density & & & & & & & \\
$>$ 25\% of employees from ethnic minorities & 6.4 & 29.6 & 34.7 & 29.2 & 19.7 & 35.7 & 33.5 & 11.1 \\
& $(1.2)$ & $(2.2)$ & $(2.3)$ & $(2.2)$ & $(1.9)$ & $(2.3)$ & $(2.2)$ & $(1.5)$ \\
$1-24 \%$ & 6.6 & 25.4 & 37.5 & 30.6 & 28.9 & 36.0 & 25.4 & 9.7 \\
& $(0.3)$ & $(0.5)$ & $(0.6)$ & $(0.6)$ & $(0.6)$ & $(0.6)$ & $(0.6)$ & $(0.4)$ \\
\hline 0\% of employees from ethnic minorities & 9.3 & 30.6 & 38.0 & 22.0 & 40.4 & 32.6 & 20.2 & 6.8 \\
& $(0.4)$ & $(0.7)$ & $(0.7)$ & $(0.6)$ & $(0.7)$ & $(0.7)$ & $(0.6)$ & $(0.4)$ \\
\hline
\end{tabular}

Notes: Standard error of mean value shown in parentheses. L (low wages) means wages less than £141 per week; M1 (lower middle) means wages between $£ 141$ and $£ 260$ per week, M2 (higher middle) means wages between $£ 261$ and $£ 360$ per week and $\mathrm{H}$ (high wages) means wages above $£ 360$ per week. 
TABLE 4: Summary of Main Results

\begin{tabular}{|c|c|c|c|c|c|c|c|c|c|c|c|c|}
\hline & \multicolumn{3}{|c|}{ BASIC } & \multicolumn{3}{|c|}{ EXTENDED 1} & \multicolumn{3}{|c|}{ EXTENDED 2} & \multicolumn{3}{|c|}{ EXTENDED 3} \\
\hline & $\beta$ & $t$-stat & ME & $\beta$ & $t$-stat & ME & $\beta$ & $t$-stat & ME & $\beta$ & t-stat & ME \\
\hline \multicolumn{13}{|l|}{ MALES } \\
\hline \multicolumn{13}{|l|}{ Job Satisfaction Models } \\
\hline Ratio of ethnic minorities to whites & -0.629 & -4.75 & -0.16 & -0.703 & -4.20 & -0.17 & -0.532 & -2.99 & -0.13 & -0.468 & -2.34 & -0.12 \\
\hline \multicolumn{13}{|l|}{ Wage Models } \\
\hline Ratio of ethnic minorities to whites & 0.188 & 2.25 & - & 0.158 & 2.10 & - & 0.117 & 1.85 & & 0.123 & 1.91 & - \\
\hline \multicolumn{13}{|l|}{ FEMALES } \\
\hline \multicolumn{13}{|l|}{ Job Satisfaction Models } \\
\hline Ratio of ethnic minorities to whites & -0.339 & -2.22 & -0.10 & -0.389 & -1.96 & -0.11 & -0.215 & -1.06 & -0.06 & -0.137 & -0.68 & -0.04 \\
\hline \multicolumn{13}{|l|}{ Wage Models } \\
\hline Ratio of ethnic minorities to whites & 0.165 & 2.37 & - & 0.159 & 2.29 & - & 0.071 & 1.18 & - & 0.065 & 1.08 & - \\
\hline
\end{tabular}

Notes: The full sets of parameter estimates for each of the models are given in Table A1-A4 in the appendix. ME is the marginal effect (estimated from the ordered probit random effects models) calculated at the means of the explanatory variables and setting the (workplace) random effects terms to be equal to zero. 
TABLE A1: The Determinants of Job Satisfaction for White Males:

Ordered Probit (Workplace) Random Effects Estimates

\begin{tabular}{|c|c|c|c|c|c|c|c|c|c|}
\hline \multirow[t]{2}{*}{ Explanatory Variables } & \multicolumn{2}{|c|}{ BASIC } & \multicolumn{2}{|c|}{ EXTENDED 1} & \multicolumn{2}{|c|}{ EXTENDED 2} & \multicolumn{3}{|c|}{ EXTENDED 3} \\
\hline & $\beta$ & $t$-stat & $\beta$ & $t$-stat & $\beta$ & $t$-stat & $\beta$ & $t$-stat & ME \\
\hline Percentage of ethnic minorities / 100 & -0.629 & -4.75 & -0.703 & -4.20 & -0.532 & -2.99 & -0.468 & -2.34 & -0.124 \\
\hline Age 25-29 & -0.222 & -4.63 & -0.140 & -2.80 & -0.137 & -2.66 & -0.112 & -2.18 & -0.024 \\
\hline Age 30-39 & -0.239 & -5.18 & -0.118 & -2.40 & -0.119 & -2.36 & -0.032 & -0.62 & -0.007 \\
\hline Age 40-49 & -0.184 & -3.81 & -0.032 & -0.61 & -0.036 & -0.68 & 0.090 & 1.65 & 0.021 \\
\hline Age 50-59 & -0.039 & -0.77 & 0.126 & 2.30 & 0.119 & 2.12 & 0.245 & 4.28 & 0.060 \\
\hline Age $>60$ & 0.369 & 5.31 & 0.587 & 7.96 & 0.566 & 7.55 & 0.614 & 7.94 & 0.176 \\
\hline Married / Co-habiting & 0.004 & 0.16 & 0.005 & 0.19 & 0.006 & 0.22 & 0.002 & 0.09 & 0.001 \\
\hline Dependant children & -0.001 & -0.03 & 0.007 & 0.20 & 0.004 & 0.10 & 0.015 & 0.42 & 0.003 \\
\hline Long-term health condition & -0.192 & -4.43 & -0.188 & -4.15 & -0.185 & -4.08 & -0.174 & -3.79 & -0.036 \\
\hline Degree or equivalent & -0.284 & -7.01 & -0.264 & -6.19 & -0.277 & -6.27 & -0.264 & -5.98 & -0.056 \\
\hline 'A' level or equivalent & -0.272 & -6.67 & -0.258 & -6.09 & -0.260 & -6.02 & -0.247 & -5.71 & -0.051 \\
\hline 'O' level or equivalent & -0.215 & -6.12 & -0.208 & -5.76 & -0.210 & -5.70 & -0.194 & -5.22 & -0.041 \\
\hline CSE or equivalent & -0.068 & -1.69 & -0.069 & -1.67 & -0.075 & -1.78 & -0.069 & -1.62 & -0.015 \\
\hline Manager & 0.358 & 6.77 & 0.243 & 4.15 & 0.206 & 3.38 & 0.233 & 3.72 & 0.057 \\
\hline Protessional & 0.060 & 1.16 & 0.052 & 0.92 & 0.013 & 0.22 & 0.026 & 0.42 & 0.006 \\
\hline Technical & -0.169 & -3.22 & -0.163 & -2.85 & -0.168 & -2.81 & -0.148 & -2.43 & -0.031 \\
\hline Clerical & -0.221 & -3.98 & -0.231 & -3.86 & -0.219 & -3.49 & -0.187 & -2.96 & -0.038 \\
\hline Craft & -0.114 & -2.47 & -0.093 & -1.82 & -0.117 & -2.14 & -0.096 & -1.74 & -0.021 \\
\hline Services & -0.017 & -0.29 & -0.105 & -1.50 & -0.128 & -1.65 & -0.091 & -1.16 & -0.020 \\
\hline Operator & -0.374 & -8.03 & -0.341 & -6.54 & -0.332 & -6.01 & -0.349 & -6.21 & -0.069 \\
\hline Other & -0.208 & -4.15 & -0.156 & -2.83 & -0.157 & -2.70 & -0.172 & -2.91 & -0.036 \\
\hline Log weekly wages (pre-tax ) & 0.396 & 13.61 & 0.335 & 10.17 & 0.379 & 10.80 & 0.396 & 11.16 & 0.089 \\
\hline Log hours & -0.404 & -10.41 & -0.385 & -9.04 & -0.372 & -8.42 & -0.382 & -8.78 & -0.086 \\
\hline Works at home & 0.234 & 7.22 & 0.198 & 5.25 & 0.205 & 5.37 & 0.207 & 5.39 & 0.050 \\
\hline Temporary job & 0.133 & 2.72 & 0.123 & 2.45 & 0.133 & 2.59 & 0.330 & 6.52 & 0.085 \\
\hline Trade union member & -0.175 & -8.24 & -0.191 & -7.27 & -0.151 & -4.72 & -0.112 & -3.47 & -0.025 \\
\hline$<1$ year with current firm & 0.258 & 6.90 & 0.218 & 5.39 & 0.215 & 5.24 & 0.234 & 5.74 & 0.057 \\
\hline 1 - 2 years with current firm & 0.099 & 2.53 & 0.071 & 1.67 & 0.067 & 1.55 & 0.111 & 2.52 & 0.026 \\
\hline 3 - 5 years with current firm & 0.081 & 2.68 & 0.070 & 2.16 & 0.064 & 1.92 & 0.079 & 2.39 & 0.018 \\
\hline 6 - 10 years with current firm & -0.012 & -0.39 & 0.002 & 0.07 & -0.002 & -0.07 & 0.002 & 0.06 & 0.001 \\
\hline Log regional house prices & 0.000 & -1.67 & 0.012 & 0.24 & 0.006 & 0.12 & 0.007 & 0.12 & 0.002 \\
\hline Unemployment rate (travel-to-work-area) & 0.003 & 0.53 & 0.006 & 0.76 & 0.007 & 0.88 & 0.015 & 1.82 & 0.003 \\
\hline Agree - Job requires one to work very hard & - & - & 0.159 & 6.07 & 0.160 & 6.02 & 0.147 & 5.48 & 0.032 \\
\hline Agree - Not enough time to get job done & - & - & -0.332 & -13.87 & -0.333 & -13.55 & -0.295 & -11.71 & -0.065 \\
\hline 1-4 days of off-the-job training & - & - & 0.356 & 11.10 & 0.376 & 11.24 & 0.339 & 10.01 & 0.084 \\
\hline 5-10 days of off-the-job training & - & - & 0.200 & 7.48 & 0.208 & 7.42 & 0.194 & 6.92 & 0.045 \\
\hline Often asked advice about workplace practices & - & - & 0.611 & 20.12 & 0.607 & 19.84 & 0.556 & 17.83 & 0.147 \\
\hline$\%$ of employees working part-time & - & - & - & - & 0.002 & 2.63 & 0.002 & 2.36 & 0.001 \\
\hline$\%$ of employees who are female & - & - & - & - & 0.001 & 1.45 & 0.001 & 0.69 & 0.000 \\
\hline Equal opportunities policy in force & - & - & - & - & -0.008 & -0.22 & -0.003 & -0.08 & -0.001 \\
\hline Trade union density at workplace & - & - & - & - & 0.000 & -0.79 & 0.000 & 0.08 & 0.000 \\
\hline Log firm size (no. of employees) & - & - & - & - & -0.033 & -2.19 & -0.031 & -2.00 & -0.007 \\
\hline
\end{tabular}


TABLE A1: (Continued)

\begin{tabular}{|c|c|c|c|c|c|c|c|c|c|}
\hline Construction & - & - & - & - & 0.047 & 0.83 & 0.039 & 0.70 & 0.009 \\
\hline Wholesale & - & - & - & - & -0.153 & -3.23 & -0.189 & -3.85 & -0.040 \\
\hline Hotels and restaurants & - & - & - & - & -0.108 & -1.26 & -0.101 & -1.19 & -0.022 \\
\hline Transport & - & - & - & - & -0.123 & -2.26 & -0.140 & -2.55 & -0.030 \\
\hline Financial & - & - & - & - & -0.216 & -3.21 & -0.130 & -1.85 & -0.027 \\
\hline Other business & - & - & - & - & -0.130 & -2.39 & -0.127 & -2.30 & -0.027 \\
\hline Education & - & - & - & - & -0.115 & -1.76 & -0.238 & -3.48 & -0.048 \\
\hline Health & - & - & - & - & -0.148 & -2.14 & -0.128 & -1.83 & -0.027 \\
\hline Other & - & - & - & - & -0.107 & -1.76 & -0.126 & -1.96 & -0.027 \\
\hline Single workplace firm & - & - & - & - & 0.109 & 2.64 & 0.108 & 2.46 & 0.025 \\
\hline Owner manager firm & - & - & - & - & -0.017 & -0.34 & -0.050 & -0.93 & -0.011 \\
\hline Problem filling vacancies & - & - & - & - & -0.033 & -1.22 & -0.045 & -1.66 & -0.010 \\
\hline$\%$ of vacancies filled internally & - & - & - & - & -0.002 & -0.26 & -0.007 & -0.89 & -0.002 \\
\hline$\%$ of employees receiving off-the-job training & - & - & - & - & 0.006 & 0.82 & 0.007 & 1.09 & 0.002 \\
\hline \% of workdays lost due to absence & - & - & - & - & -0.004 & -0.93 & -0.007 & -1.68 & -0.002 \\
\hline$\%$ of workers having workplace injury & - & - & - & - & -0.351 & -1.33 & -0.384 & -1.36 & -0.086 \\
\hline Absence information missing & - & - & - & - & -0.072 & -1.81 & -0.062 & -1.53 & -0.014 \\
\hline Injury information missing & - & - & - & - & -0.011 & -0.35 & 0.003 & 0.09 & 0.001 \\
\hline$\%$ of employees $<£ 9,000$ per year & - & - & - & - & 0.000 & 0.54 & 0.000 & 0.21 & 0.000 \\
\hline$\%$ of employees $>£ 29,000$ per year & - & - & - & - & 0.000 & 1.09 & 0.000 & 1.26 & 0.000 \\
\hline Racial tensions at the workplace & - & - & - & - & - & - & 0.052 & 0.43 & 0.012 \\
\hline Discrimination at the workplace & - & - & - & - & - & - & -0.072 & -1.17 & -0.016 \\
\hline Bad conditions concerns at workplace & - & - & - & - & - & - & 0.014 & 0.42 & 0.003 \\
\hline Agree that your job is secure & - & - & - & - & - & - & 0.813 & 27.49 & 0.182 \\
\hline Indifferent about job security & - & - & - & - & - & - & 0.356 & 11.16 & \\
\hline Standard deviation of random effect & 0.071 & 3.06 & 0.213 & 12.18 & 0.194 & 10.16 & 0.198 & 10.39 & \\
\hline Log Likelihood & -16080 & & -14999 & & -14965 & & -14557 & & \\
\hline Sample & 10052 & & 10052 & & 10052 & & 10052 & & \\
\hline
\end{tabular}

Notes: The omitted categories are age less than 25, single, no children, free of long-term health condition, no qualifications, sales, does not work at home, permanent job, not a trade union member, with current firm more than 10 years, does not agree that 'my job requires that I work very hard', does not agree that 'I never seem to have enough time to get my job done', has not undertaken any employer-funded off-the-job training in last 12 months, manager does not frequently ask my views about changes to work practices, no equal opportunities policy at the workplace, manufacturing sector, multi-workplace firm, no owner manager, no problems filling vacancies in last 12 months, no problems due to racial harassment at the workplace in last 12 months, no problems due to discrimination at the workplace in last 12 months, no problems due to bad working conditions at the workplace in last 12 months and disagree with the statement 'I feel my job is secure in this workplace'. The ME is the marginal effect from Extended 3 model calculated at the means of the explanatory variables and setting the random effects term to zero. '-' means that the variable is not included in model. 
TABLE A2: The Determinants of Job Satisfaction for White Females:

Ordered Probit (Workplace) Random Effects Estimates

\begin{tabular}{|c|c|c|c|c|c|c|c|c|c|}
\hline \multirow[t]{2}{*}{ Explanatory Variables } & \multicolumn{2}{|c|}{ BASIC } & \multicolumn{2}{|c|}{ EXTENDED 1} & \multicolumn{2}{|c|}{ EXTENDED 2} & \multicolumn{3}{|c|}{ EXTENDED 3} \\
\hline & $\beta$ & $t$-stat & $\beta$ & $t$-stat & $\beta$ & $t$-stat & $\beta$ & $t$-stat & ME \\
\hline Percentage of ethnic minorities / 100 & -0.339 & -2.22 & -0.389 & -1.96 & -0.215 & -1.06 & -0.137 & -0.68 & 0.044 \\
\hline Age 25-29 & 0.036 & 0.83 & 0.088 & 1.86 & 0.084 & 1.77 & 0.115 & 2.42 & 0.033 \\
\hline Age 30-39 & 0.016 & 0.41 & 0.083 & 1.96 & 0.073 & 1.67 & 0.147 & 3.36 & 0.042 \\
\hline Age 40-49 & 0.078 & 1.85 & 0.150 & 3.32 & 0.124 & 2.68 & 0.221 & 4.74 & 0.065 \\
\hline Age 50-59 & 0.192 & 4.13 & 0.273 & 5.45 & 0.246 & 4.80 & 0.336 & 6.47 & 0.102 \\
\hline Age $>60$ & 0.561 & 6.98 & 0.637 & 7.49 & 0.605 & 6.95 & 0.640 & 7.37 & 0.216 \\
\hline Married / Co-habiting & 0.117 & 4.66 & 0.124 & 4.65 & 0.119 & 4.38 & 0.121 & 4.44 & 0.033 \\
\hline Dependant children & 0.015 & 0.42 & 0.022 & 0.58 & 0.028 & 0.73 & 0.032 & 0.83 & 0.009 \\
\hline Long-term health condition & -0.221 & -4.31 & -0.194 & -3.59 & -0.184 & -3.38 & -0.163 & -2.97 & -0.043 \\
\hline Degree or equivalent & -0.502 & -11.78 & -0.502 & -10.92 & -0.522 & -11.04 & -0.496 & -10.49 & -0.124 \\
\hline 'A' level or equivalent & -0.308 & -7.78 & -0.323 & -7.68 & -0.328 & -7.61 & -0.291 & -6.76 & -0.075 \\
\hline 'O' level or equivalent & -0.194 & -5.89 & -0.205 & -5.83 & -0.204 & -5.71 & -0.179 & -4.97 & -0.049 \\
\hline CSE or equivalent & -0.054 & -1.31 & -0.068 & -1.56 & -0.073 & -1.65 & -0.055 & -1.23 & -0.015 \\
\hline Manager & 0.430 & 7.88 & 0.367 & 6.08 & 0.361 & 5.66 & 0.385 & 6.03 & 0.121 \\
\hline Protessional & 0.229 & 4.66 & 0.233 & 4.12 & 0.164 & 2.65 & 0.162 & 2.60 & 0.047 \\
\hline Technical & 0.051 & 1.11 & 0.018 & 0.34 & 0.015 & 0.25 & 0.028 & 0.45 & 0.008 \\
\hline Clerical & -0.047 & -1.38 & -0.010 & -0.25 & -0.008 & -0.16 & 0.006 & 0.12 & 0.002 \\
\hline Craft & -0.005 & -0.06 & 0.022 & 0.21 & -0.003 & -0.03 & 0.061 & 0.54 & 0.018 \\
\hline Services & 0.111 & 2.71 & 0.004 & 0.09 & -0.042 & -0.73 & -0.006 & -0.10 & -0.002 \\
\hline Operator & -0.332 & -5.76 & -0.331 & -4.86 & -0.349 & -4.54 & -0.331 & -4.25 & -0.081 \\
\hline Other & 0.093 & 2.14 & 0.096 & 1.84 & 0.083 & 1.44 & 0.099 & 1.69 & 0.029 \\
\hline Log weekly wages (pre-tax ) & 0.255 & 9.20 & 0.229 & 7.36 & 0.258 & 7.86 & 0.276 & 8.26 & 0.077 \\
\hline Log hours & -0.332 & -10.02 & -0.337 & -9.01 & -0.334 & -8.69 & -0.335 & -8.68 & -0.094 \\
\hline Works at home & 0.364 & 8.94 & 0.344 & 7.53 & 0.341 & 7.40 & 0.355 & 7.73 & 0.111 \\
\hline Temporary job & 0.044 & 1.08 & 0.036 & 0.80 & 0.028 & 0.60 & 0.267 & 5.71 & 0.081 \\
\hline Trade union member & -0.154 & -6.67 & -0.179 & -6.54 & -0.188 & -6.11 & -0.157 & -5.08 & -0.043 \\
\hline < 1 year with current firm & 0.273 & 7.33 & 0.214 & 5.22 & 0.223 & 5.41 & 0.219 & 5.29 & 0.065 \\
\hline 1 - 2 years with current firm & 0.115 & 2.99 & 0.057 & 1.38 & 0.062 & 1.47 & 0.060 & 1.44 & 0.017 \\
\hline 3 - 5 years with current firm & 0.076 & 2.39 & 0.054 & 1.57 & 0.059 & 1.69 & 0.069 & 1.99 & 0.020 \\
\hline 6 - 10 years with current firm & 0.009 & 0.27 & -0.004 & -0.11 & -0.002 & -0.04 & 0.006 & 0.18 & 0.002 \\
\hline Log regional house prices & 0.000 & -3.26 & -0.090 & -1.71 & -0.105 & -1.93 & -0.121 & -2.19 & -0.034 \\
\hline Unemployment rate (travel-to-work-area) & -0.009 & -1.52 & -0.011 & -1.31 & -0.010 & -1.25 & -0.008 & -0.99 & -0.002 \\
\hline Agree - Job requires one to work very hard & - & - & 0.177 & 5.96 & 0.181 & 5.99 & 0.157 & 5.18 & 0.042 \\
\hline Agree - Not enough time to get job done & - & - & -0.337 & -13.90 & -0.343 & -14.00 & -0.320 & -12.88 & -0.088 \\
\hline 1-4 days of off-the-job training & - & - & 0.297 & 8.45 & 0.309 & 8.64 & 0.284 & 7.92 & 0.086 \\
\hline 5-10 days of off-the-job training & - & - & 0.172 & 6.76 & 0.173 & 6.64 & 0.161 & 6.10 & 0.046 \\
\hline Often asked advice about workplace practices & - & - & 0.560 & 17.43 & 0.557 & 17.26 & 0.502 & 15.78 & 0.157 \\
\hline$\%$ of employees working part-time & - & - & - & - & 0.003 & 3.38 & 0.002 & 3.15 & 0.001 \\
\hline$\%$ of employees who are female & - & - & - & - & 0.000 & -0.39 & -0.001 & -0.90 & 0.000 \\
\hline Equal opportunities policy in force & - & - & - & - & -0.090 & -2.33 & -0.059 & -1.49 & -0.017 \\
\hline Trade union density at workplace & - & - & - & - & 0.001 & 1.41 & 0.001 & 2.28 & 0.000 \\
\hline Log firm size (no. of employees) & - & - & - & - & -0.010 & -0.66 & -0.011 & -0.77 & -0.003 \\
\hline
\end{tabular}


TABLE A2: (Continued)

\begin{tabular}{|c|c|c|c|c|c|c|c|c|c|}
\hline Construction & - & - & - & - & -0.003 & -0.04 & -0.007 & -0.07 & -0.002 \\
\hline Wholesale & - & - & - & _ & -0.150 & -2.45 & -0.210 & -3.41 & -0.056 \\
\hline Hotels and restaurants & - & - & - & - & -0.071 & -0.86 & -0.098 & -1.17 & -0.026 \\
\hline Transport & - & - & - & - & -0.180 & -2.27 & -0.209 & -2.57 & -0.054 \\
\hline Financial & - & - & - & - & -0.238 & -3.57 & -0.170 & -2.44 & -0.045 \\
\hline Other business & - & - & - & - & 0.014 & 0.23 & -0.009 & -0.14 & -0.002 \\
\hline Education & - & - & - & - & 0.013 & 0.21 & -0.054 & -0.84 & -0.015 \\
\hline Health & - & - & - & - & -0.107 & -1.67 & -0.089 & -1.37 & -0.025 \\
\hline Other & - & - & - & - & -0.117 & -1.59 & -0.116 & -1.48 & -0.031 \\
\hline Single workplace firm & - & - & - & - & -0.025 & -0.64 & -0.035 & -0.89 & -0.010 \\
\hline Owner manager firm & - & - & - & - & 0.096 & 1.87 & 0.072 & 1.31 & 0.021 \\
\hline Problem filling vacancies & - & - & - & - & -0.068 & -2.47 & -0.071 & -2.54 & -0.020 \\
\hline$\%$ of vacancies filled internally & - & - & - & - & 0.007 & 0.95 & -0.003 & -0.39 & -0.001 \\
\hline$\%$ of employees receiving off-the-job training & - & - & - & - & -0.009 & -1.24 & -0.004 & -0.54 & -0.001 \\
\hline$\%$ of workdays lost due to absence & - & - & - & - & 0.001 & 0.37 & 0.000 & 0.02 & 0.000 \\
\hline \% of workers having workplace injury & - & - & - & - & -1.096 & -3.19 & -1.152 & -3.51 & -0.323 \\
\hline Absence information missing & - & - & - & - & -0.053 & -1.32 & -0.062 & -1.56 & -0.017 \\
\hline Injury information missing & - & - & - & - & -0.013 & -0.39 & -0.017 & -0.52 & -0.005 \\
\hline$\%$ of employees $<£ 9,000$ per year & - & - & - & - & -0.001 & -1.66 & -0.001 & -2.38 & 0.000 \\
\hline$\%$ of employees $>£ 29,000$ per year & - & - & - & - & 0.000 & 1.09 & 0.000 & 1.25 & 0.000 \\
\hline Racial tensions at the workplace & - & - & - & - & - & - & -0.008 & -0.07 & -0.002 \\
\hline Discrimination at the workplace & - & - & - & - & - & - & -0.031 & -0.46 & -0.009 \\
\hline Bad conditions concerns at workplace & - & - & - & - & - & - & -0.027 & -0.71 & -0.008 \\
\hline Agree that your job is secure & - & - & - & - & - & - & 0.753 & 23.76 & 0.199 \\
\hline Indifferent about job security & - & - & - & - & - & - & -0.001 & -0.68 & 0.080 \\
\hline Standard deviation of random effect & 0.071 & 2.76 & 0.228 & 12.28 & 0.202 & 10.70 & 0.200 & 7.79 & \\
\hline Log Likelihood & -16117 & & -15174 & & -15128 & & -14790 & & \\
\hline Sample & 10085 & & 10085 & & 10085 & & 10085 & & \\
\hline
\end{tabular}

Notes: The omitted categories are age less than 25, single, no children, free of long-term health condition, no qualifications, sales, does not work at home, permanent job, not a trade union member, with current firm more than 10 years, does not agree that 'my job requires that I work very hard', does not agree that 'I never seem to have enough time to get my job done', has not undertaken any employer-funded off-the-job training in last 12 months, manager does not frequently ask my views about changes to work practices, no equal opportunities policy at the workplace, manufacturing sector, multi-workplace firm, no owner manager, no problems filling vacancies in last 12 months, no problems due to racial harassment at the workplace in last 12 months, no problems due to discrimination at the workplace in last 12 months, no problems due to bad working conditions at the workplace in last 12 months and disagree with the statement 'I feel my job is secure in this workplace'. The ME is the marginal effect from Extended 3 model calculated at the means of the explanatory variables and setting the random effects term to zero. '-' means that the variable is not included in model. 
TABLE A3: The Determinants of Log Weekly Wages for White Males:

Random Effects Interval Regression Estimates

\begin{tabular}{|c|c|c|c|c|c|c|c|c|}
\hline \multirow[t]{2}{*}{ Explanatory Variables } & \multicolumn{2}{|c|}{ BASIC } & \multicolumn{2}{|c|}{ EXTENDED 1} & \multicolumn{2}{|c|}{ EXTENDED 2} & \multicolumn{2}{|c|}{ EXTENDED 3} \\
\hline & $\beta$ & $t$-stat & $\beta$ & $t$-stat & $\beta$ & $t$-stat & $\beta$ & $t$-stat \\
\hline Percentage of ethnic minorities / 100 & 0.188 & 2.25 & 0.158 & 2.10 & 0.117 & 1.85 & 0.123 & 1.91 \\
\hline Age 25-29 & 0.250 & 13.71 & 0.257 & 14.10 & 0.223 & 13.30 & 0.224 & 13.37 \\
\hline Age 30-39 & 0.355 & 19.92 & 0.364 & 20.37 & 0.328 & 20.03 & 0.329 & 20.08 \\
\hline Age 40-49 & 0.397 & 21.08 & 0.410 & 21.64 & 0.388 & 22.09 & 0.388 & 22.16 \\
\hline Age 50-59 & 0.381 & 19.09 & 0.396 & 19.69 & 0.380 & 20.47 & 0.380 & 20.49 \\
\hline Age $>60$ & 0.212 & 8.27 & 0.237 & 9.30 & 0.247 & 10.41 & 0.247 & 10.46 \\
\hline Married / Co-habiting & 0.105 & 12.19 & 0.103 & 12.11 & 0.086 & 11.23 & 0.085 & 11.16 \\
\hline Dependant children & 0.041 & 4.10 & 0.040 & 4.10 & 0.042 & 4.77 & 0.043 & 4.79 \\
\hline Long-term health condition & -0.034 & -2.17 & -0.032 & -2.06 & -0.030 & -2.39 & -0.030 & -2.40 \\
\hline Degree or equivalent & 0.265 & 17.51 & 0.263 & 17.48 & 0.263 & 18.94 & 0.263 & 18.96 \\
\hline 'A' level or equivalent & 0.142 & 10.07 & 0.138 & 9.79 & 0.133 & 10.36 & 0.133 & 10.36 \\
\hline 'O' level or equivalent & 0.082 & 6.77 & 0.079 & 6.60 & 0.086 & 7.93 & 0.086 & 7.91 \\
\hline CSE or equivalent & 0.023 & 1.66 & 0.022 & 1.59 & 0.037 & 2.96 & 0.037 & 2.95 \\
\hline & 0.487 & 18.78 & 0.467 & 18.45 & 0.421 & 19.30 & 0.420 & 19.27 \\
\hline Professional & 0.393 & 14.84 & 0.382 & 14.72 & 0.344 & 15.15 & 0.343 & 15.09 \\
\hline Technical & 0.285 & 11.07 & 0.278 & 10.99 & 0.183 & 8.35 & 0.182 & 8.30 \\
\hline Clerical & 0.094 & 3.53 & 0.092 & 3.54 & -0.005 & -0.22 & -0.006 & -0.25 \\
\hline Craft & 0.122 & 4.86 & 0.126 & 5.13 & 0.052 & 2.43 & 0.051 & 2.40 \\
\hline Services & -0.158 & -3.95 & -0.172 & -4.23 & -0.107 & -2.61 & -0.106 & -2.59 \\
\hline Operator & -0.025 & -0.96 & -0.010 & -0.40 & -0.088 & -4.06 & -0.088 & -4.08 \\
\hline Other & -0.178 & -6.89 & -0.163 & -6.47 & -0.147 & -6.45 & -0.148 & -6.45 \\
\hline Log hours & 0.697 & 23.64 & 0.694 & 23.40 & 0.606 & 20.81 & 0.606 & 20.82 \\
\hline Works at home & 0.148 & 11.08 & 0.136 & 10.35 & 0.093 & 7.87 & 0.093 & 7.84 \\
\hline Temporary job & -0.152 & -6.63 & -0.148 & -6.48 & -0.122 & -6.06 & -0.122 & -6.06 \\
\hline Trade union member & 0.094 & 8.88 & 0.086 & 8.20 & 0.048 & 4.87 & 0.048 & 4.88 \\
\hline$<1$ year with current firm & -0.160 & -10.81 & -0.166 & -11.19 & -0.125 & -9.36 & -0.125 & -9.31 \\
\hline 1 - 2 years with current firm & -0.145 & -9.72 & -0.151 & -10.05 & -0.106 & -7.96 & -0.106 & -7.89 \\
\hline 3 - 5 years with current firm & -0.093 & -8.50 & -0.094 & -8.69 & -0.055 & -5.65 & -0.054 & -5.59 \\
\hline 6 - 10 years with current firm & -0.062 & -6.02 & -0.059 & -5.83 & -0.034 & -3.62 & -0.034 & -3.59 \\
\hline Log regional house prices & 0.262 & 11.51 & 0.269 & 12.01 & 0.246 & 12.27 & 0.245 & 12.22 \\
\hline Unemployment rate (travel-to-work-area) & -0.005 & -1.31 & -0.004 & -1.10 & -0.006 & -1.97 & -0.006 & -1.91 \\
\hline Agree - Job requires one to work very hard & - & - & 0.004 & 0.41 & 0.011 & 1.35 & 0.010 & 1.30 \\
\hline Agree - Not enough time to get job done & - & - & -0.023 & -3.00 & -0.013 & -1.81 & -0.012 & -1.78 \\
\hline 1-4 days of off-the-job training & - & - & 0.090 & 8.01 & 0.052 & 5.04 & 0.052 & 5.07 \\
\hline 5-10 days of off-the-job training & - & - & 0.064 & 7.53 & 0.044 & 5.62 & 0.045 & 5.64 \\
\hline Often asked advice about workplace practices & - & - & 0.039 & 3.88 & 0.052 & 5.39 & 0.051 & 5.37 \\
\hline \% of employees working part-time & - & - & - & - & -0.005 & -12.38 & -0.005 & -12.33 \\
\hline$\%$ of employees who are female & - & - & - & - & 0.001 & 2.40 & 0.001 & 2.35 \\
\hline Equal opportunities policy in force & - & - & - & - & 0.011 & 0.74 & 0.011 & 0.74 \\
\hline Trade union density at workplace & - & - & - & - & 0.001 & 2.49 & 0.001 & 2.42 \\
\hline Log firm size (no. of employees) & - & - & - & - & 0.027 & 4.77 & 0.027 & 4.76 \\
\hline
\end{tabular}


TABLE A3: (Continued)

\begin{tabular}{|c|c|c|c|c|c|c|c|c|}
\hline Construction & - & - & 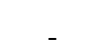 & - & -0.005 & -0.25 & -0.004 & -0.21 \\
\hline Wholesale & - & - & _- & - & -0.034 & -188 & & -185 \\
\hline Hotels and restaurants & - & - & - & - & -0.134 & -4.37 & -0.134 & -4.40 \\
\hline Transport & - & - & - & - & -0.054 & -2.76 & -0.052 & -2.65 \\
\hline Financial & - & - & - & - & 0.061 & 2.33 & 0.064 & 2.39 \\
\hline Other business & - & - & - & - & -0.030 & -1.34 & -0.029 & -1.28 \\
\hline Education & - & - & - & - & -0.128 & -5.46 & -0.127 & -5.39 \\
\hline Health & - & - & - & - & -0.114 & -4.22 & -0.113 & -4.17 \\
\hline Other & - & - & - & - & -0.074 & -3.13 & -0.073 & -3.07 \\
\hline Single workplace firm & - & - & - & - & -0.013 & -0.84 & -0.014 & -0.87 \\
\hline Owner manager firm & - & - & - & - & -0.025 & -1.26 & -0.024 & -1.19 \\
\hline Problem filling vacancies & - & - & - & - & 0.011 & 1.05 & 0.011 & 1.03 \\
\hline$\%$ of vacancies filled internally & - & - & - & - & -0.006 & -2.09 & -0.006 & -2.15 \\
\hline$\%$ of employees receiving off-the-job training & - & - & - & - & -0.002 & -0.89 & -0.003 & -0.91 \\
\hline$\%$ of workdays lost due to absence & - & - & - & - & -0.002 & -1.19 & -0.002 & -1.22 \\
\hline$\%$ of workers having workplace injury & - & - & - & - & 0.168 & 1.75 & 0.159 & 1.70 \\
\hline Absence information missing & - & - & - & - & -0.026 & -1.72 & -0.027 & -1.80 \\
\hline Injury information missing & - & - & - & - & & & 0.046 & 3.93 \\
\hline$\%$ of employees $<£ 9,000$ per year & - & - & - & - & -0.001 & -3.11 & -0.001 & -3.34 \\
\hline$\%$ of employees $>£ 29,000$ per year & - & - & - & - & 0.001 & 6.48 & 0.001 & 6.74 \\
\hline Racial tensions at the workplace & - & - & - & - & - & - & 0.019 & 0.39 \\
\hline Discrimination at the workplace & - & - & - & - & - & - & -0.019 & -0.96 \\
\hline Bad conditions concerns at workplace & - & - & - & - & - & - & 0.012 & 0.90 \\
\hline Agree that your job is secure & - & - & - & - & - & - & 0.002 & 0.22 \\
\hline Indifferent about job security & - & - & - & - & - & - & -0.002 & -0.28 \\
\hline Log Likelihood & -18429 & & -18353 & & -17566 & & -17563 & \\
\hline Sample & 10052 & & 10052 & & 10052 & & 10052 & \\
\hline
\end{tabular}

Notes: The omitted categories are age less than 25, single, no children, free of long-term health condition, no qualifications, sales, does not work at home, permanent job, not a trade union member, with current firm more than 10 years, does not agree that 'my job requires that I work very hard', does not agree that 'I never seem to have enough time to get my job done', has not undertaken any employer-funded off-the-job training in last 12 months, manager does not frequently ask my views about changes to work practices, no equal opportunities policy at the workplace, manufacturing sector, multi-workplace firm, no owner manager, no problems filling vacancies in last 12 months, no problems due to racial harassment at the workplace in last 12 months, no problems due to discrimination at the workplace in last 12 months, no problems due to bad working conditions at the workplace in last 12 months and disagree with the statement 'I feel my job is secure in this workplace'. '-' means that the variable is not included in model. The standard errors have been adjusted for workplace clustering. 
TABLE A4: The Determinants of Log Weekly Wages for White Females:

Random Effects Interval Regression Estimates

\begin{tabular}{|c|c|c|c|c|c|c|c|c|}
\hline \multirow[t]{2}{*}{ Explanatory Variables } & \multicolumn{2}{|c|}{ BASIC } & \multicolumn{2}{|c|}{ EXTENDED 1} & \multicolumn{2}{|c|}{ EXTENDED 2} & \multicolumn{2}{|c|}{ EXTENDED 3} \\
\hline & $\beta$ & $t$-stat & $\beta$ & $t$-stat & $\beta$ & $t$-stat & $\beta$ & $t$-stat \\
\hline Percentage of ethnic minorities / 100 & 0.165 & 2.37 & 0.159 & 2.29 & 0.071 & 1.18 & 0.065 & 1.08 \\
\hline Age 25-29 & 0.163 & 11.23 & 0.162 & 11.22 & 0.126 & 9.45 & 0.126 & 9.46 \\
\hline Age 30-39 & 0.233 & 15.55 & 0.231 & 15.43 & 0.202 & 14.90 & 0.202 & 14.86 \\
\hline Age 40-49 & 0.220 & 15.03 & 0.219 & 14.98 & 0.212 & 15.92 & 0.212 & 15.84 \\
\hline Age 50-59 & 0.208 & 12.59 & 0.209 & 12.67 & 0.207 & 13.69 & 0.207 & 13.60 \\
\hline Age $>60$ & 0.127 & 4.46 & 0.130 & 4.62 & 0.140 & 5.36 & 0.140 & 5.39 \\
\hline Married / Co-habiting & 0.007 & 0.84 & 0.006 & 0.73 & 0.007 & 1.01 & 0.007 & 0.99 \\
\hline Dependant children & 0.060 & 5.11 & 0.059 & 5.01 & 0.054 & 4.93 & 0.054 & 4.95 \\
\hline Long-term health condition & -0.062 & -4.18 & -0.061 & -4.10 & -0.056 & -3.86 & -0.057 & -3.92 \\
\hline Degree or equivalent & 0.343 & 21.60 & 0.337 & 21.13 & 0.320 & 21.52 & 0.319 & 21.38 \\
\hline 'A' level or equivalent & 0.193 & 14.44 & 0.188 & 14.08 & 0.173 & 14.26 & 0.172 & 14.20 \\
\hline 'O' level or equivalent & 0.134 & 11.77 & 0.130 & 11.44 & 0.122 & 11.73 & 0.121 & 11.69 \\
\hline CSE or equivalent & 0.029 & 2.23 & 0.027 & 2.04 & 0.040 & 3.32 & 0.039 & 3.26 \\
\hline Manager & 0.562 & 26.03 & 0.550 & 25.75 & 0.453 & 21.78 & 0.453 & 21.73 \\
\hline Professional & 0.470 & 21.49 & 0.458 & 21.20 & 0.394 & 17.25 & 0.394 & 17.21 \\
\hline Technical & 0.353 & 16.46 & 0.345 & 16.11 & 0.235 & 10.35 & 0.235 & 10.34 \\
\hline Clerical & 0.262 & 15.80 & 0.263 & 16.03 & 0.106 & 5.80 & 0.107 & 5.80 \\
\hline Craft & 0.080 & 2.49 & 0.093 & 2.89 & 0.003 & 0.09 & 0.003 & 0.11 \\
\hline Services & 0.002 & 0.10 & -0.006 & -0.27 & -0.008 & -0.35 & -0.008 & -0.37 \\
\hline Operator & 0.044 & 1.83 & 0.064 & 2.64 & -0.095 & -4.10 & -0.094 & -4.04 \\
\hline Other & -0.120 & -6.13 & -0.115 & -5.95 & -0.148 & -7.25 & -0.147 & -7.21 \\
\hline Log hours & 0.933 & 51.87 & 0.920 & 50.30 & 0.847 & 46.51 & 0.846 & 46.51 \\
\hline Works at home & 0.139 & 9.22 & 0.133 & 8.88 & 0.087 & 5.92 & 0.088 & 5.95 \\
\hline Temporary job & -0.064 & -3.37 & -0.061 & -3.23 & -0.063 & -3.37 & -0.066 & -3.52 \\
\hline Trade union member & 0.097 & 9.66 & 0.090 & 8.98 & 0.074 & 7.28 & 0.074 & 7.26 \\
\hline$<1$ year with current firm & -0.144 & -10.73 & -0.144 & -10.60 & -0.129 & -10.28 & -0.129 & -10.27 \\
\hline 1 - 2 years with current firm & -0.118 & -8.82 & -0.121 & -9.12 & -0.112 & -9.23 & -0.112 & -9.21 \\
\hline 3 - 5 years with current firm & -0.092 & -8.72 & -0.092 & -8.79 & -0.080 & -8.30 & -0.081 & -8.37 \\
\hline 6 - 10 years with current firm & -0.050 & -5.15 & -0.050 & -5.17 & -0.037 & -4.06 & -0.037 & -4.08 \\
\hline Log regional house prices & 0.240 & 10.05 & 0.243 & 10.16 & 0.221 & 10.50 & 0.221 & 10.47 \\
\hline Unemployment rate (travel-to-work-area) & 0.004 & 1.27 & 0.004 & 1.27 & 0.026 & 2.97 & 0.026 & 2.96 \\
\hline Agree - Job requires one to work very hard & - & - & 0.024 & 2.48 & 0.020 & 2.67 & 0.020 & 2.63 \\
\hline Agree - Not enough time to get job done & - & - & 0.011 & 1.35 & 0.031 & 3.20 & 0.031 & 3.23 \\
\hline 1-4 days of off-the-job training & - & - & 0.045 & 4.19 & 0.048 & 5.96 & 0.047 & 5.97 \\
\hline 5-10 days of off-the-job training & - & - & 0.052 & 6.08 & 0.041 & 4.97 & 0.042 & 5.00 \\
\hline Often asked advice about workplace practices & - & - & 0.020 & 2.24 & -0.004 & -11.76 & -0.004 & -11.91 \\
\hline \% of employees working part-time & - & - & - & - & 0.000 & 1.37 & 0.000 & 1.39 \\
\hline$\%$ of employees who are female & - & - & - & - & 0.018 & 1.14 & 0.018 & 1.17 \\
\hline Equal opportunities policy in force & - & - & - & - & 0.000 & 2.09 & 0.000 & 2.10 \\
\hline Trade union density at workplace & - & - & - & - & 0.025 & 4.76 & 0.024 & 4.51 \\
\hline Log firm size (no. of employees) & - & - & - & - & -0.018 & -0.71 & -0.019 & -0.78 \\
\hline
\end{tabular}


TABLE A4: (Continued)

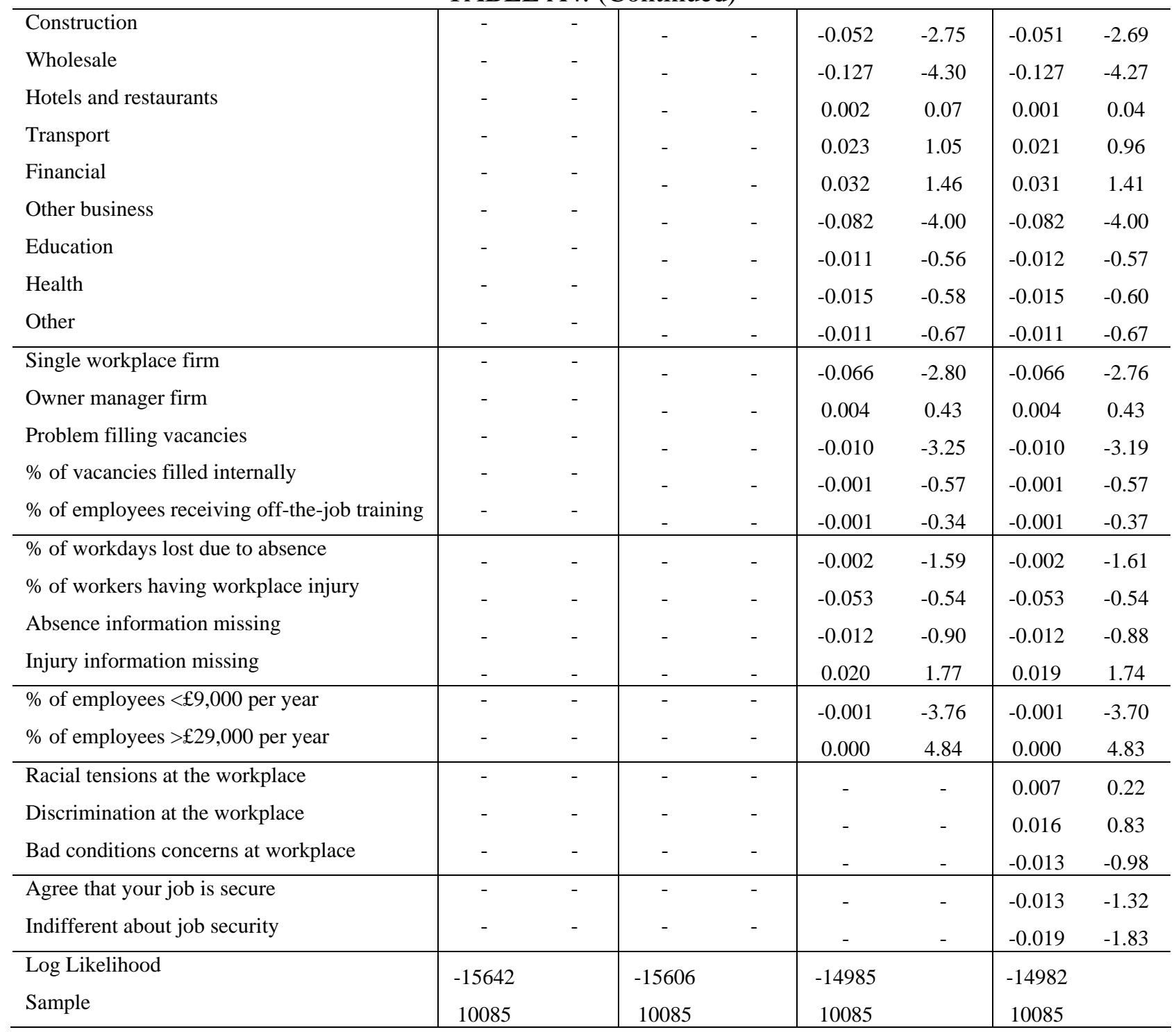

Notes: The omitted categories are age less than 25, single, no children, free of long-term health condition, no qualifications, sales, does not work at home, permanent job, not a trade union member, with current firm more than 10 years, does not agree that 'my job requires that I work very hard', does not agree that 'I never seem to have enough time to get my job done', has not undertaken any employer-funded off-the-job training in last 12 months, manager does not frequently ask my views about changes to work practices, no equal opportunities policy at the workplace, manufacturing sector, multi-workplace firm, no owner manager, no problems filling vacancies in last 12 months, no problems due to racial harassment at the workplace in last 12 months, no problems due to discrimination at the workplace in last 12 months, no problems due to bad working conditions at the workplace in last 12 months and disagree with the statement 'I feel my job is secure in this workplace'. '-' means that the variable is not included in model. The standard errors have been adjusted for workplace clustering. 


\section{University Library}

\section{- M M I N E R VA A gateway to Melbourne's research publications}

Minerva Access is the Institutional Repository of The University of Melbourne

Author/s:

Frijters, Paul;Shields, Michael A.;Theodoropoulos, Nikolaos;Price, Stephen Wheatley

Title:

Testing for employee discrimination using matched employer-employee data: theory and evidence

Date:

2004-09

Citation:

Frijters, Paul and Shields, Michael A. and Theodoropoulos, Nikolaos and Price, Stephen Wheatley (2004) Testing for employee discrimination using matched employer-employee data: theory and evidence.

Persistent Link:

http://hdl.handle.net/11343/34378 